\title{
Can Transition Metals and Group II Mono- and Dications Discriminate between Homo- and Heterochiral XYYX' Dimers $\left(\mathrm{X}, \mathrm{X}^{\prime}=\mathrm{H}, \mathrm{Me} ; \mathrm{Y}=\mathbf{O}, \mathrm{S}, \mathrm{Se}\right) ?^{\dagger}$
}

\author{
Kathy J. Chen, ${ }^{a}$ Otilia Mó, ${ }^{\mathrm{b}}$ Manuel Yáñez, ${ }^{\mathrm{b}}$ and Inés Corral ${ }^{\mathrm{b}, *}$ \\ ${ }^{a}$ Laboratoire CEISAM - UMR CNRS 6230, Université de Nantes, 2 Rue de la Houssinière, \\ BP 92208, 44322 Nantes Cedex 3, France \\ ${ }^{\mathrm{b}}$ Departamento de Química, Universidad Autónoma de Madrid, 28049, Cantoblanco, Madrid, Spain
}

RECEIVED JUNE 13, 2014; REVISED NOVEMBER 11, 2014; ACCEPTED NOVEMBER 10, 2014

\begin{abstract}
We present a density functional theory and ab initio (MP2) study of stereoisomer discrimination between the homochiral and heterochiral dimers of the form $\mathrm{M}(\mathrm{XYYX})_{2}$, where $\mathrm{M}$ is a cationic metal $\left(\mathrm{Li}^{+}, \mathrm{Ca}^{2+}, \mathrm{Zn}^{2+}, \mathrm{Cu}^{+}, \mathrm{Cu}^{2+}\right)$ complexing chalcogen-chalcogen bridges $\left(\mathrm{H}_{2} \mathrm{O}_{2}, \mathrm{H}_{2} \mathrm{~S}_{2}, \mathrm{H}_{2} \mathrm{Se}_{2}\right.$, and their corresponding methyl and dimethyl derivatives). The heterochiral complexes examined were in general found to be more stable than the homochiral complexes, with the exception of several selenium-containing complexes. The large majority of the relative energy differences amounted to $1 \mathrm{~kJ} / \mathrm{mol}$ or less, with the largest energy gap being $3.42 \mathrm{~kJ} / \mathrm{mol}$ in the case of $\mathrm{Ca}^{2+}\left(\mathrm{HSeSe}\left(\mathrm{CH}_{3}\right)\right)_{2}$ at $\mathrm{B} 3 \mathrm{LYP} /$ aug-cc-pVTZ. Racemization mechanisms of these complexes and the description of their bonding using the Atoms in Molecules theory of Bader are also presented.
\end{abstract}

Keywords: stereoselectivity, organometallic complex, chirality, DFT, MP2

\section{INTRODUCTION}

Metal-driven chiral discrimination, i.e. the enantioselective complexation of chiral substrates by metal cations, has been the driving force for many advances in the fields of biochemistry, organic synthesis and medicine. The interest in chirally-selective organometallic coordination has led to numerous investigations of stereoselective complexation and its dependence on the nature of the metal and ligands involved in the coordination. ${ }^{1-5}$ Experimental mass spectrometry studies have utilized a variety of charged metals to differentiate diastereomeric complexes based on their stabilities. ${ }^{6,7}$ Tao et al., for instance, using a variant of the kinetic method, successfully employed $\mathrm{Cu}$ (II) to discriminate homo-/heterochiral $\mathrm{D}$ and $\mathrm{L}$ amino acid mixtures in the gas phase, obtaining enantiomeric excesses of 0.47 to 11 in favor of the heterochiral structure despite energetic differences as small as $1 \mathrm{~kJ} / \mathrm{mol}^{8-10}$ Paladini et al. achieved enantiodiscrimination of chiral $\alpha$-aminophosphonic acid cationic clusters, with stability differences ranging from $1.8-2.3 \mathrm{~kJ} / \mathrm{mol}$, using $\mathrm{H}, \mathrm{Li}$, Na or K cations. ${ }^{11}$ Such chiral recognition hinges upon the great sensitivity of the fragmentation kinetics of metallic complexes to the energy difference between the two complexes containing the analyte enantiomers, regardless of the minute differences in ion stability between the enantiomers.

The use of metals in chiral recognition techniques, especially those able to coordinate several ligands, i.e. transition metals, not only meets experimental technical requirements but also has fundamental biological and biochemical implications, considering that metalloorganic interactions are prevalent in biological and metabolic processes. Zinc and copper, for example, not only serve as cofactors in hundreds of known enzymes, but are also common cores used to chirally resolve isomers in stereoselective organic synthesis due to their ability to stably coordinate multiple ligands. ${ }^{12,13}$ Though less frequently involved in chelation than the transition metals, calcium-complexed proteins, characterized by their EF-hand motif, are ubiquitous in biological functions as well. Since calcium-binding proteins ligate to the positively charged calcium ion via negatively charged residues, these same proteins are also responsive to the concentration of ionic $\mathrm{Li}^{+}$in the surroundings. ${ }^{14,15}$ For all these cationic metals, the

\footnotetext{
$\dagger$ Dedicated to Dr. Mirjana Eckert-Maksić on the occasion of her $70^{\text {th }}$ birthday.

* Author to whom correspondence should be addressed. (E-mail: ines.corral@uam.es)
} 


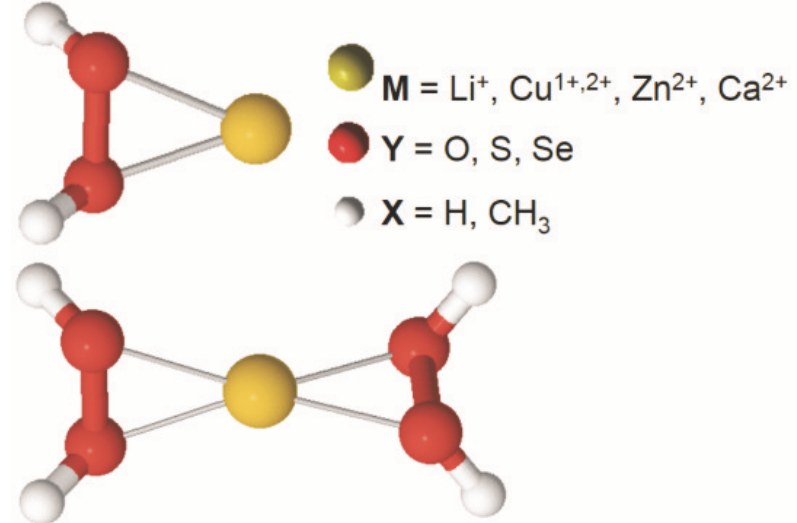

(a) ML and ML2 complexes

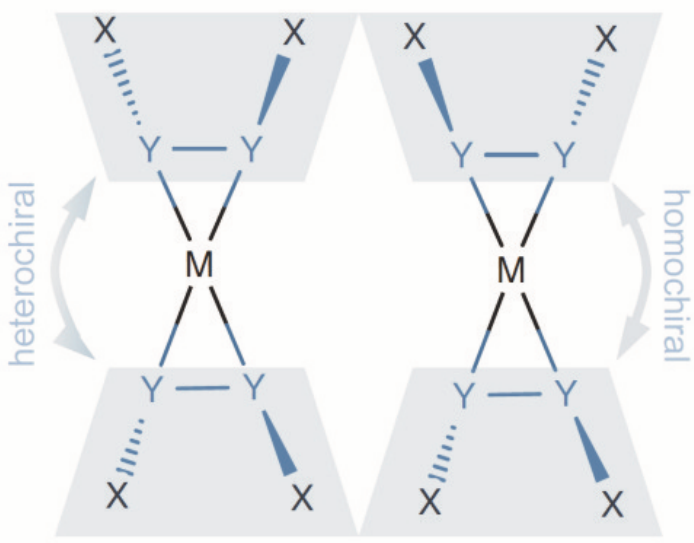

(b) Heterochiral and homochiral isomers

Figure 1. Schemes depicting structures of $\mathrm{M}(\mathrm{XYYX})_{1,2}$ complexes.

chelation of proteins and peptides typically occurs at the side chains of amino acids with electronegative heteroatoms such as oxygen, sulfur, and occasionally selenium. ${ }^{16,17}$

Computational studies complement mass spectrometry experiments with enormous predictive power in both interpreting results and for guiding the rationale design of ion ligand complexation reactions for stereoselective recognition of enantiomers in the gas phase. In this line, the contributions by the group of Alkorta and Elguero are numerous. ${ }^{18-27}$ For instance, a recent chiral distinction study by this group considered bisligand systems of $\mathrm{Li}^{+}$coordinating peroxide ligands $\left(\mathrm{Li}(\mathrm{XOOX})_{1,2}\right.$ where $\left.\mathrm{X}=\mathrm{H}, \mathrm{Me}\right)$ at the MP2 level. The study had determined that although heterochiral complexes were consistently more stable than their homochiral counterparts, the stabilization differences were less than chemical accuracy. ${ }^{28}$ Sánchez-Sanz et al. carried out a similar study on homochiral and heterochiral dimers of chalcogen-chalcogen bridges $\left((\mathrm{HTeYH})_{2}\right.$ where $\left.\mathrm{Y}=\mathrm{O}, \mathrm{S}, \mathrm{Se}, \mathrm{Te}\right)$ using DFT methods. Though metal coordination was not considered, their investigation concluded that stability differences between the two stereoisomers amounted to less than $0.7 \mathrm{kcal} / \mathrm{mol}$, with the sole exception of $(\mathrm{HTeSeH})_{2}$ exhibiting a relative energy difference of $2 \mathrm{kcal} / \mathrm{mol}$ in favor of the heterochiral configuration. ${ }^{29}$

In this present investigation, we perform a systematic study of mono and bisligand complexes of the form $\mathrm{M}(\mathrm{XYYX})_{1,2}$ in order to characterize their capability for stereoisomeric discrimination. The chiral center $\mathrm{M}$ was chosen as one from among the alkali, alkaline earth, or first row transition metals: $\mathrm{Li}^{+}, \mathrm{Ca}^{2+}$, $\mathrm{Cu}^{+}, \mathrm{Cu}^{2+}$, or $\mathrm{Zn}^{2+}$. The ligands in the coordinate sphere are chalcogen bridges of the form XYYX, where the chalcogen $\mathrm{Y}$ is a member of the oxygen group of among oxygen, sulfur, and selenium, and $\mathrm{X}$ is varied as either hydrogen or methyl. These bidentate ligands feature lone pairs that repelled by the bonding electrons in the molecule, stick out prominently and are readily accessible for complexation by the metal. As can be seen in Figure 1, the complexes exhibit axial chirality. Together, the homochiral and heterochiral complexes form a diastereomeric pair, sharing the same connectivity but differing in their spatial arrangement of the substituent groups on the ligand molecule. The ligands of the homochiral ML2 complexes possess the same XYYX dihedral angle, while the dihedrals formed by the ligand atoms in the heterochiral ML2 complexes show opposite signs.

The effects of changing the ligand, metal, and coordination number upon the relative energies of the isomers have been evaluated at the DFT and MP2/augcc-pVTZ levels of theory. For the combination of each ligand and metal, a total of 36 heterochiral and 48 homochiral ML2 (2:1) structures were optimized, see Figures 1a and 2. The corresponding monoligand (1:1) structures, all together 36 complexes, were also optimized for completeness, see Figure 1a. For each pair of homochiral and heterochiral dimers, their relative energies were compared in order to gauge the metal cation potential for stereodiscrimination in the complexes. For select pairs, we have also located transition state structures involved in the racemization pathway between the two isomers. Atoms in Molecules (AIM) analyses were carried out in order to characterize the nature of the bonding or non-bonding interaction between the metals and their ligands. Lastly, we comment on the relationship between stereoisomeric differentiation and the structural and thermochemical trends observed in the series of complexes.

\section{CALCULATION DETAILS}

All structures were fully optimized at both the B3LYP and MP2 level of theory using the correlation-consistent 


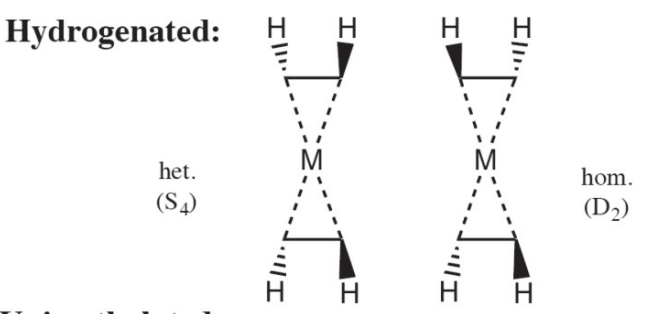

Unimethylated:

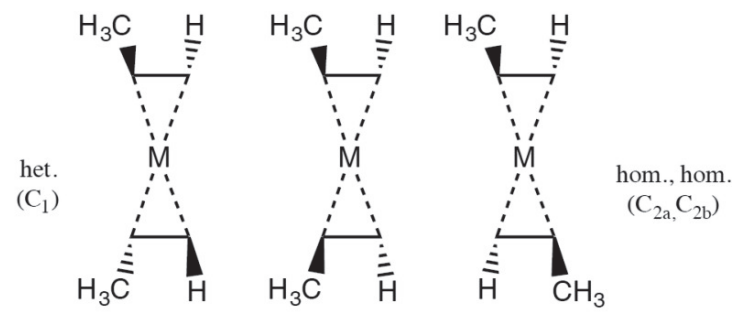

Dimethylated:

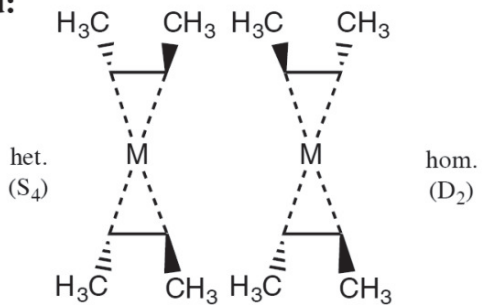

Figure 2. Summary of all the $\mathrm{M}(\mathrm{XYYX})_{2}$ complexes, classified according to their symmetry.

aug-cc-pVTZ basis, which had been previously utilized in similar studies for describing correlation in metallic dication species. ${ }^{28,30}$ To account for the correlation of core electrons of the metal ${ }^{31}$ and since calcium is absent from the standard aug-cc-pVTZ basis set, calcium was instead described using the CVTZ basis of J. Martin et $\mathrm{al}^{32}$ Depending on the nature of the ligands and the axial chirality of the complexes, the ligands were optimized under the following symmetry constraints: ligands in heterochiral hydrogen and dimethylated complexes were arranged around the central metal according to $S_{4}$ symmetry, whereas no symmetry constraints were considered for unimethylated complexes, recall Figure 2. In turn, $D_{2}$ and $C_{2}$ environments around the metal were considered for hydrogenated or dimethylated and unimethylated homochiral complexes, respectively. Note that two different $C_{2}$ homochiral complexes, $C_{2} a$ and $C_{2} b$, are possible for unimethylated complexes. In those cases where symmetry constraints lead to the optimization of stationary points of second order or above, transition states were relaxed to their ground state minima by reducing the enforced symmetries in the order of $S_{4} \rightarrow$ $D_{2} \rightarrow C_{2} \rightarrow C_{1}$ until a stable minimum had been obtained with the highest possible symmetry. Frequency calculations were run on all final structures at the same level of theory in order to ensure that all geometries had arrived at their equilibrium geometries.
Because spin contamination is a crucial factor in determining the reliability of a wavefunction, the $S^{2}$ values of representative complexes were carefully checked and were found to be well within $2 \%$ of their expected values, signifying no significant spin contamination. Single point CCSD calculations were carried out to obtain $T_{1}$ diagnostic values for representative complexes at their MP2/aug-cc-pVTZ optimized geometries in order to gauge the multireference nature of their wavefunctions. The $T_{1}$ diagnostic of Lee et al. determines the contribution of non-dynamic electron correlation as the Euclidean norm of the $t_{1}$ vector of the coupled cluster wavefunction scaled by the number of correlated electrons $N:^{33}$

$$
T_{1}=\frac{\left|t_{1}\right|}{\sqrt{N}}
$$

Whereas the $T_{1}$ values for most complexes were well under the generally accepted limit of 0.02 , the values for the $\mathrm{Cu}(\mathrm{I})$ complexes hovered around 0.015 to 0.02 , and those of $\mathrm{Cu}$ (II) ranged from 0.03 to 0.05 . Based on these results, the outlying data values obtained for several $\mathrm{Cu}$ (II) complexes were understood to be an artifact of the inadequate monodeterminant treatment of the system. Since a multireference study of the $\mathrm{Cu}$ (II) doublet is beyond the scope of this study, only the proclivity of their complexes to deprotonate was considered (see Deprotonation energies section). These complexes, however, were excluded from our stability and bonding analysis, leaving 120 complexes.

Transition state searches were carried out using the Synchronous Transit-Guided Quasi-Newton (QST2 and QST3) methods at the B3LYP/aug-cc-pVTZ level in order to map the interconversion pathway between the homo-/heterochiral stereoisomers. Subsequent frequency calculations confirmed that the final structures corresponded to first order transition states.

Relative stabilities, metal-ligand interaction energies and racemization barriers include non-scaled zero point energy corrections.

All of the aforementioned calculations were performed using the Gaussian09 package. ${ }^{34}$ In order to characterize the nature of the metal-ligand bonding, we conducted Atoms in Molecules analyses (AIM) using the AIMAll package ${ }^{35}$ for the wavefunctions of all 120 MP2/aug-cc-pVTZ optimized structures: the 36 monomers, 36 heterochiral dimers and 48 homochiral dimers. At the bond critical point (BCP) of the metal-ligand bonds, we have considered three topological characteristics: the Laplacian of the density $\left(\nabla^{2} \rho\right)$, the bond ellipticity $(\varepsilon)$, the total electronic energy density $\left(H_{\mathrm{BCP}}\right)$ calculated as the sum:

$$
H_{\mathrm{BCP}}=G_{\mathrm{BCP}}+V_{\mathrm{BCP}}
$$




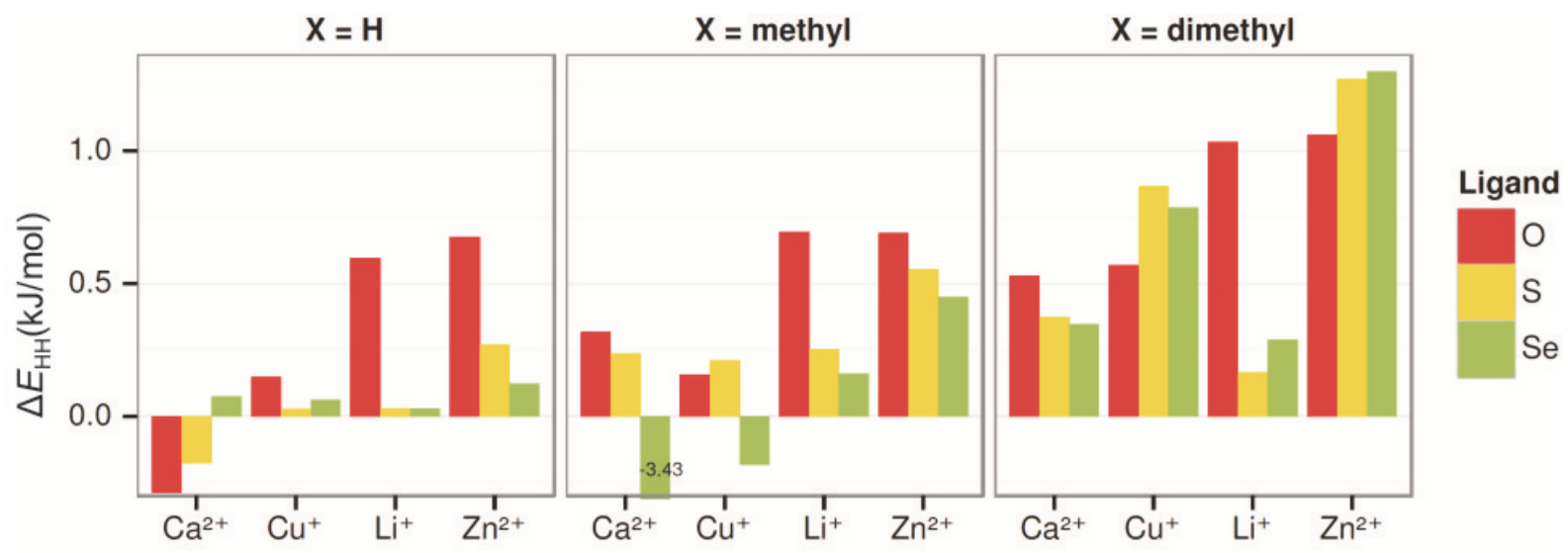

(a) $\Delta E_{\mathrm{HH}}$, B3LYP/aug-cc-pVTZ
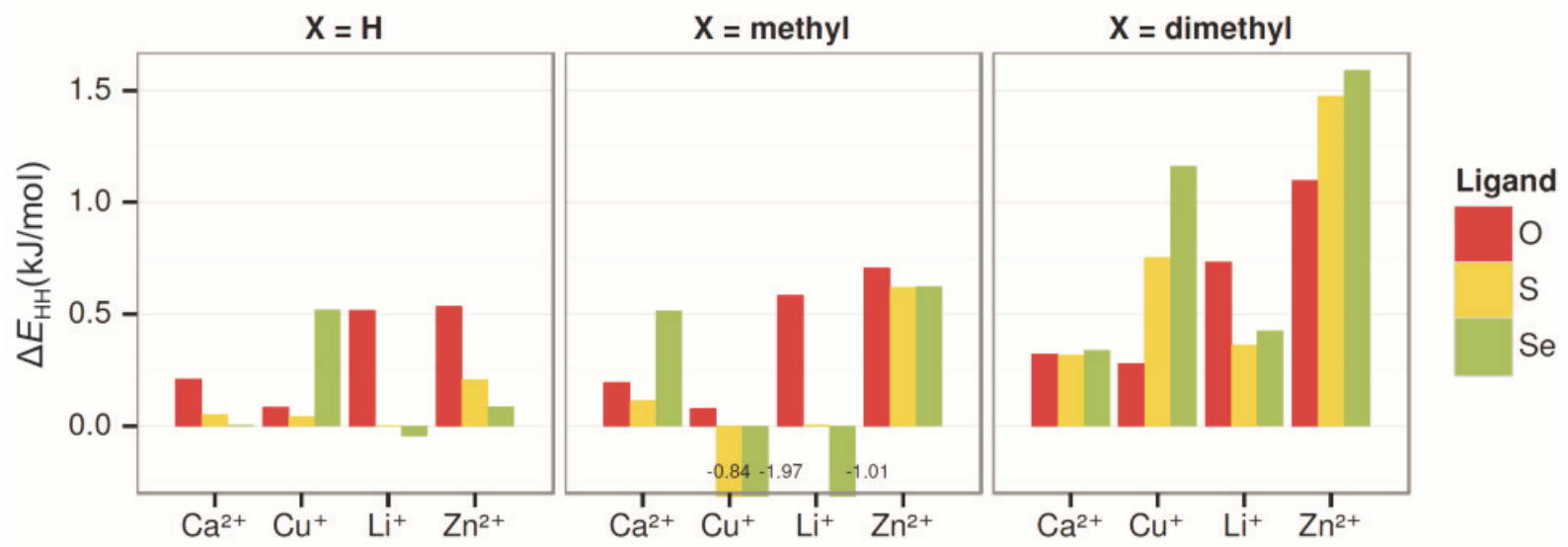

(b) $\Delta E_{H H}, M P 2 / a u g-c c-p V T Z$

Figure 3. Relative stabilities $\left(\Delta E_{\mathrm{HH}}\right.$, in $\left.\mathrm{kJ} / \mathrm{mol}\right)$ between homochiral and heterochiral complexes. Positive values indicate that the heterochiral complex is more stable than its homochiral counterpart.

where $G_{\mathrm{BCP}}$ is the contribution of the kinetic energy density and $V_{\mathrm{BCP}}$ is the potential energy density.

\section{RESULTS AND DISCUSSION}

\section{Energy Differences between Homo-/Heterochiral Complexes}

As the primary goal of this study is to thermochemically differentiate the homo- and heterochiral stereoisomers, we define $\Delta E_{\mathrm{HH}}$ for the sake of convenience to equal the relative stability between the homochiral and heterochiral complex, calculated as E(homochiral) $E$ (heterochiral). For the methylated complexes with two possible homochiral stereoisomers, the value of $E$ (homochiral) was taken to be the average between the two $\mathrm{C}_{2} a$ and $\mathrm{C}_{2} b$ isomers, which differ minimally by less than $0.02 \mathrm{~kJ} / \mathrm{mol}$ on average. The values of $\Delta E_{\mathrm{HH}}$ at the MP2 and B3LYP levels of theory across the series of all metals and ligands have been gathered in Figure 3. The results suggest that none of the possible combi- nations of the four metals with nine ligands were able to energetically discriminate between the two complexes, since none of the computed values for $\Delta E_{\mathrm{HH}}$ were greater than chemical accuracy of $4 \mathrm{~kJ} / \mathrm{mol}$.

In our study, we point out that relative energies from the two levels of theory agree to a large extent; the discrepancies between MP2 and DFT are below chemical accuracy, with differences typically less than 1 $\mathrm{kJ} / \mathrm{mol}$ due to the sensitive nature of enantiomeric distinction. However, for particular combinations of metal cations and neutrals these two methods predict opposite stability ordering, as can be seen in a comparison of Figures. 3(a) and 3(b). Discrepancies between DFT and MP2 have been documented before - for copper, zinc, and other transition metals, a number of studies have shown that the B3LYP functional yields geometric and energetic results in good agreement with experimental values, while MP2 gives bond orders and bond dissociation values that are too low. ${ }^{36,37}$ In studies of $\mathrm{Cu}(\mathrm{I})$ bound with small ligands, DFT results were able to reproduce the correct experimental energy ordering of 
Table 1. Metal-ligand interaction energies $\left(E_{\text {inter, }} \mathrm{kJ} / \mathrm{mol}\right)$ for $\mathrm{M}(\mathrm{HYYH})_{1,2}$ complexes

\begin{tabular}{|c|c|c|c|c|c|c|c|}
\hline \multirow[b]{2}{*}{ Metal } & \multirow[b]{2}{*}{ Compl. } & \multicolumn{3}{|c|}{$E_{\text {inter, }}$ B3LYP } & \multicolumn{3}{|c|}{$E_{\text {inter, }}$ MP2 } \\
\hline & & $\mathrm{O}$ & $\mathrm{S}$ & $\mathrm{Se}$ & $\mathrm{O}$ & $\mathrm{S}$ & $\mathrm{Se}$ \\
\hline $\mathrm{Ca}^{2+}$ & $1: 1$ & 262.8 & 253.5 & 292.2 & 226.7 & 223.6 & 247.3 \\
\hline $\mathrm{Ca}^{2+}$ & $2: 1$, homo & 492.6 & 455.2 & 484.0 & 432.8 & 399.1 & 438.1 \\
\hline $\mathrm{Ca}^{2+}$ & $2: 1$, het & 492.4 & 455.0 & 484.0 & 433.0 & 399.1 & 438.1 \\
\hline $\mathrm{Cu}^{+}$ & $1: 1$ & 155.9 & 181.3 & 208.2 & 149.1 & 175.3 & 207.0 \\
\hline $\mathrm{Cu}^{+}$ & 2:1, homo & 310.9 & 361.3 & 346.8 & 308.5 & 372.7 & 398.8 \\
\hline $\mathrm{Cu}^{+}$ & $2: 1$, het & 311.1 & 361.3 & 346.8 & 308.5 & 372.7 & 398.8 \\
\hline $\mathrm{Li}^{+}$ & $1: 1$ & 147.1 & 110.3 & 115.2 & 139.1 & 101.9 & 112.2 \\
\hline $\mathrm{Li}^{+}$ & $2: 1$, homo & 266.2 & 190.5 & 193.9 & 256.6 & 186.3 & 210.5 \\
\hline $\mathrm{Li}^{+}$ & $2: 1$, het & 266.8 & 190.5 & 193.9 & 257.1 & 186.3 & 210.5 \\
\hline $\mathrm{Zn}^{2+}$ & $1: 1$ & 442.4 & 587.1 & 665.2 & 421.4 & 538.0 & 610.0 \\
\hline $\mathrm{Zn}^{2+}$ & 2:1, homo & 785.9 & 929.6 & 1012.1 & 763.4 & 896.4 & 992.1 \\
\hline $\mathrm{Zn}^{2+}$ & $2: 1$, het & 785.9 & 929.6 & 1012.1 & 763.4 & 896.4 & 992.1 \\
\hline
\end{tabular}

the ligands while overestimating molecule-to-metal charge transfers and over-stabilizing the complex - an error absent from MP2. ${ }^{37,38}$

In general, the larger the ligand, the larger the value of $\Delta E_{\mathrm{HH}}$, which was on average $0.73 \mathrm{~kJ} / \mathrm{mol}$ more for the dimethylated ligands than the hydrogenated or unimethylated ligands. As for the dependence of $\Delta E_{\mathrm{HH}}$ on the chalcogen, oxygen produced the largest $\Delta E_{\mathrm{HH}}$ with B3LYP, in average excess of $0.30 \mathrm{~kJ} / \mathrm{mol}$ in 9 of 12 homo-heterochiral pairs grouped by metal type. With MP2, however, oxygen produced the largest average $\Delta E_{\mathrm{HH}}$ in only 5 of 12 pairs by $0.39 \mathrm{~kJ} / \mathrm{mol}$, while selenium produced the greatest average $\Delta E_{\mathrm{HH}}$ of $0.67 \mathrm{~kJ} / \mathrm{mol}$ in 6 of 12 pairs. Lastly, grouping the results by ligand type, we observed that of the four central metal cations, $\mathrm{Zn}(\mathrm{II})$ produced the largest $\Delta E_{\mathrm{HH}}$ by on average of 0.40 $\mathrm{kJ} / \mathrm{mol}$ more than the other metals in 8 of 9 homoheterochiral pairs grouped by ligand type. In MP2, $\mathrm{Zn}$ (II) continues to predominate in excess of 0.57 $\mathrm{kJ} / \mathrm{mol}$ in 5 of 9 pairs.

We carry out an examination of the metal-ligand interaction energies, as summarized in Tables 1 and SIV of the Supporting Information, containing respecttively the results for $\mathrm{M}(\mathrm{HYYH})_{1,2}$ and the rest of the complexes studied. The differences between MP2 and B3LYP become again apparent in the interaction energies, which can amount up to $80 \mathrm{~kJ} / \mathrm{mol}$. In general we find that MP2 predicts ca. $7 \%$ lower interaction energies compared to B3LYP. In particular, the bigger differences are found for $\mathrm{Ca}^{2+}$ complexes and $\mathrm{Cu}(\mathrm{I})$ complexes coordinated to selenium ligands. The first conspicuous fact in Tables 1 and S-IV is that the interaction energies of $\mathrm{Cu}(\mathrm{I})$ and $\mathrm{Zn}$ (II) transition metal complexes are remarkably larger compared to those found for their analogous complexes containing the alkaline and alkaline earth cations with the same net charge. This reflects important differences in the bonding of both kinds of complexes that will be further discussed in section Bonding trends and AIM analysis of the Discussion. In fact, $\mathrm{Cu}(\mathrm{I})$ B3LYP interaction energies were calculated to be 1.1-1.8 times the ones of $\mathrm{Li}(\mathrm{I})$ whereas those of $\mathrm{Zn}$ (II) were computed to be 1.7 to 2.3 times larger than those of $\mathrm{Ca}$ (II). These ratios are consistent with the availability of $4 \mathrm{~s}$ orbitals of transition metals to accept charge from the ligands leading to dative bonds. In agreement with a previous study, ${ }^{28}$ no important cooperative effects were found for these systems; that is, the interaction energies calculated for the 2:1 complexes are approximately twice those computed for the 1:1 complexes. The only exception are $\mathrm{Zn}^{2+} / \mathrm{Se}$ complexes for which B3LYP/MP2 predict a difference of 1.5 between the interaction energies of the ML and ML2 complexes.

\section{Structural Trends}

We have structurally characterized all the 2:1 complexes by their average metal-ligand distance as well as their ligand-metal-ligand dihedrals, both of which are reported for the $\mathrm{M}(\mathrm{HYYH})_{2}$ series in Tables 2 and 3; the values for the remainder of the complexes are in Tables S-I and S-II of the Supporting Information. Bond lengths have been averaged over the four metalchalcogen bonds for each ML2 complex. Even for complexes with $C_{1}$ symmetry, the four distances were virtually identical with average standard deviations of less than $1 \times 10^{-5} \AA$. Depending on the nature of the chelating chalcogen, metal-ligand bond lengths respected the pattern $\mathrm{Se}>\mathrm{S}>\mathrm{O}$ following atomic radius trends along the group. Metal-ligand bond lengths also 
Table 2. Average metal-ligand bond lengths (in $\AA$ ) of $\mathrm{M}(\mathrm{HYYH})_{2}$ complexes optimized at B3LYP and MP2/aug-cc-pVTZ. Asterisks indicate $\mathrm{Cu}-\mathrm{Y}$ bond lengths reported for two- instead of four-coordinated complexes. See discussion in Section Structural trends and Figure 5

\begin{tabular}{|c|c|c|c|c|c|c|c|}
\hline \multirow[b]{2}{*}{ Metal } & \multirow[b]{2}{*}{ Compl. } & \multicolumn{3}{|c|}{ B3LYP bond lengths } & \multicolumn{3}{|c|}{ MP2 bond lengths } \\
\hline & & $\mathrm{Y}=\mathrm{O}$ & $\mathrm{Y}=\mathrm{S}$ & $\mathrm{Y}=\mathrm{Se}$ & $\mathrm{Y}=\mathrm{O}$ & $\mathrm{Y}=\mathrm{S}$ & $\mathrm{Y}=\mathrm{Se}$ \\
\hline $\mathrm{Ca}^{2+}$ & homo & 2.422 & 2.972 & 3.038 & 2.457 & 2.930 & 3.046 \\
\hline $\mathrm{Cu}^{+}$ & homo & $* 2.269$ & $* 2.266$ & 2.331 & *2.303 & $* 2.731$ & 2.359 \\
\hline $\mathrm{Li}^{+}$ & homo & 1.989 & 2.541 & 2.562 & 2.008 & 2.515 & 2.602 \\
\hline $\mathrm{Zn}^{2+}$ & homo & 2.022 & 2.408 & 2.452 & 2.022 & 2.368 & 2.471 \\
\hline $\mathrm{Ca}^{2+}$ & het & 2.422 & 2.973 & 3.038 & 2.457 & 2.930 & 3.046 \\
\hline $\mathrm{Cu}^{+}$ & het & $* 2.236$ & $* 2.263$ & 2.330 & *2.307 & $* 2.730$ & 2.359 \\
\hline $\mathrm{Li}^{+}$ & het & 1.988 & 2.540 & 2.537 & 2.006 & 2.515 & 2.601 \\
\hline $\mathrm{Zn}^{2+}$ & het & 2.023 & 2.406 & 2.451 & 2.021 & 2.368 & 2.471 \\
\hline
\end{tabular}

exhibited the trend of hydrogenated $>$ methylated ligands, reflecting the increase in polarizability upon the substitution of the ligand with methyl groups. As for the dependence on the metal, apart for the less polarizable oxygen ligands, metal-ligands bond lengths exhibit the pattern of $\mathrm{Ca}^{2+}>\mathrm{Li}^{+}>\mathrm{Zn}^{2+}>\mathrm{Cu}^{+}$, mirroring the relative strength of the bondings. The ordering also reflects the ionic radius ordering of the cation: $\mathrm{Li}^{+}(0.74$ $\AA), \mathrm{Zn}^{2+}(0.75 \AA)$ and $\mathrm{Cu}^{+}(0.77 \AA)$ show similar ionic sizes but are smaller compared to $\mathrm{Ca}^{2+}(1.00 \AA)$ ). Further discussion on the characteristics of the bonding of the complexes can be found in the following section. In accordance to the energetic trends discussed in the previous section, the more stable heterochiral compounds generally exhibited slightly shorter metalligand bond lengths than their homochiral counterparts by $0.09 \%(0.002 \AA)$. As usual, $\mathrm{Cu}(\mathrm{I})$ compounds were the exception; homochiral compounds coordinated with $\mathrm{Cu}(\mathrm{I})$ had longer metal-ligand bonds by $0.15 \%(0.004$ $\AA$ ). Between the two levels of theory, B3LYP and MP2 bond lengths were in general agreement with average discrepancies of $0.08 \AA$, except for the $\mathrm{Cu}(\mathrm{I})(\mathrm{XSSX})_{2}$ complexes where MP2 overestimates metal-ligand distances by more than ca. $0.4 \AA$.

The dihedral angle, measured as the difference between the angle formed by the two planes of the four metal-ligand bonds, is the most salient structural difference between the homo-/heterochiral complexes, see Figure 4. Dihedral angles for $\mathrm{M}(\mathrm{HYYH})_{2}$ and the rest of bisligand complexes are collected in Tables 3 and S-I from the Supporting Information, respectively. The dihedrals of the complexes vary according to the optimal configuration for coordinating covalent bonds between the central metal and the chalcogen ligands. A majority of the heterochiral complexes (DFT: 30/36 structures, MP2: 33/36 structures) exhibited an 80-90 dihedral such that the two metal-ligand planes are perpendicular to one another (see Tables 3 and S-I from the Supporting Information). By contrast, almost all the homochiral complexes (DFT: 43/48 structures, MP2: $35 / 48$ structures) displayed significant distortion away from the perpendicular configuration. The values calculated with MP2 and DFT agree on average within 0.8 degree for the homochiral complexes and within 1.5

Table 3. Dihedral angles (deg) of $\mathrm{M}(\mathrm{HYYH})_{2}$ complexes optimized at B3LYP and MP2/aug-cc-pVTZ

\begin{tabular}{|c|c|c|c|c|c|c|c|}
\hline \multirow[b]{2}{*}{ Metal } & \multirow[b]{2}{*}{ Compl. } & \multicolumn{3}{|c|}{ B3LYP dihedral angles } & \multicolumn{3}{|c|}{ MP2 dihedral angles } \\
\hline & & $\mathrm{Y}=\mathrm{O}$ & $\mathrm{Y}=\mathrm{S}$ & $\mathrm{Y}=\mathrm{Se}$ & $\mathrm{Y}=\mathrm{O}$ & $\mathrm{Y}=\mathrm{S}$ & $\mathrm{Y}=\mathrm{Se}$ \\
\hline $\mathrm{Ca}^{2+}$ & het & 90.0 & 90.0 & 90.0 & 90.0 & 90.0 & 90.0 \\
\hline $\mathrm{Cu}^{+}$ & het & 47.0 & 72.5 & 90.0 & 72.2 & 81.1 & 90.0 \\
\hline $\mathrm{Li}^{+}$ & het & 90.0 & 90.0 & 90.0 & 90.0 & 90.0 & 90.0 \\
\hline $\mathrm{Zn}^{2+}$ & het & 90.0 & 90.0 & 90.0 & 90.0 & 90.0 & 90.0 \\
\hline $\mathrm{Ca}^{2+}$ & homo & 71.5 & 64.9 & 78.4 & 70.9 & 64.8 & 69.2 \\
\hline $\mathrm{Cu}^{+}$ & homo & 56.1 & 63.5 & 74.9 & 89.5 & 56.3 & 76.2 \\
\hline $\mathrm{Li}^{+}$ & homo & 87.3 & 64.0 & 71.5 & 87.6 & 61.7 & 66.5 \\
\hline $\mathrm{Zn}^{2+}$ & homo & 73.4 & 78.8 & 82.4 & 74.3 & 79.2 & 82.7 \\
\hline
\end{tabular}



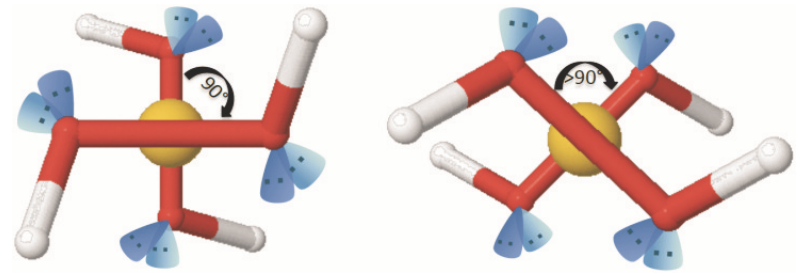

Figure 4. Illustration of the spatial orientation of lone pairs in heterochiral (left) and homochiral (right) dimers.

degrees for the heterochiral complexes; however, the angles for $\mathrm{Cu}(\mathrm{I})$ differ by on average 6 degrees between the two levels of theory. As per the results of the evaluating the multiconfigurational quality of the wavefunction for $\mathrm{Cu}$, these differences are attributable to the different manner of treating electron correlation in B3LYP and MP2.

At first glance (see Figure 4), this notable difference in the geometry of homo and heterochiral complexes could be attributed to either stabilizing hydrogen bonding or destabilizing steric interactions between two opposite ligands. However, the distance between the two opposite ligands is sufficiently large ( $>4 \AA$ ) to prevent a substantial interaction between the two substituents. In order to gain further insight into the origin of this structural difference, we constrained the dihedral defined by the planes containing the metal and the two $\mathrm{Y}$ chalcogen atoms to equal $90^{\circ}$ in all the 2:1 $\left(\mathrm{Ca}(\mathrm{XOOX})_{2}\right)^{2+}$ homochiral complexes and recomputed the energy at this point of the multidimensional PES. Interestingly, all the new constrained complexes showed an energy only $0.5 \mathrm{~kJ} / \mathrm{mol}$ above the optimized homochiral complexes, supporting our hypothesis that neither stabilizing nor destabilizing interactions between the two opposite ligands are taking place at such a large distance.
One structural difference worthy of mention that differentiates $\mathrm{Cu}(\mathrm{I})$ from the rest of the metals is its tendency to bond preferentially to only one oxygen or sulfur atom in the ligand, rather than bonding simultaneously to both chalcogens of the bridge, as is the case of $\mathrm{Cu}(\mathrm{I})(\mathrm{XOOX}), \mathrm{Cu}(\mathrm{I})(\mathrm{XOOX})_{2}$, and $\mathrm{Cu}(\mathrm{I})(\mathrm{XSSX})_{2}$ complexes, see Figure 5. All other optimized complexes, including $\mathrm{Cu}(\mathrm{I})(\mathrm{XSeSeX})_{1,2}$, maintain the usual structure formed by the two or four chelation sites characterizing the rest of $(1: 1)$ and $(2: 1)$ complexes included in this work. The typical bow-tie structure, however, resulted in an unstable transition state for the oxygen and sulphur $\mathrm{Cu}(\mathrm{I})$ bisligand complexes mentioned above, which preferentially relaxed into the trans structures with two chelation sites depicted in Figure 5.

These differences in the coordination pattern of $\mathrm{Cu}(\mathrm{I})$ depending on the nature of the ligand can be ascribed to the greater polarizable nature of the selenide ligands facilitating the simultaneous bonding of the metal to the two chalcogen centers of the ligand, as opposed to sulfides or peroxides which are characterized by strongly localized lone pairs.

Similar findings were put forward in a prior theoretical study of $\mathrm{Cu}(\mathrm{I})$ that confirmed its preferred coordination to two ligands rather than four when complexing weakly polarizable ligands, such as $\mathrm{NH}_{3}$ or $\mathrm{H}_{2} \mathrm{O}$. The authors attributed these results to the sharp decrease in polarization stabilization with increasing coordination number. ${ }^{39,40}$ While electrostatic contributions to the stability remain conserved, each additional complexation to a less polarizable ligand rapidly saturates the polarization contribution to stability, and hence a lower coordination number prevails.

Again in line with the work of Pavelka and Burda, ${ }^{39}$ we also find that contrary to $\mathrm{Cu}(\mathrm{I})$, higher coordinated complexes are stabilized when the metal is $\mathrm{Cu}(\mathrm{II})$.

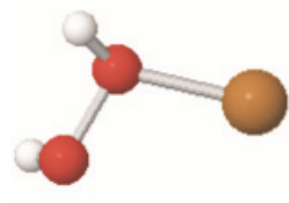

$\mathrm{Cu}(\mathrm{I})-(\mathrm{XOOX})$

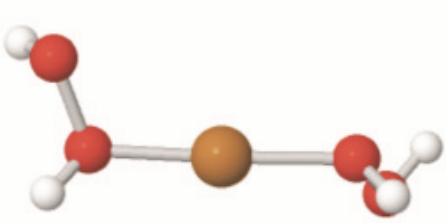

$\mathrm{Cu}(\mathrm{I})-(\mathrm{XOOX})_{2}$

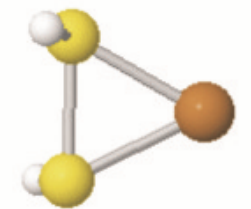

$\mathrm{Cu}(\mathrm{I})-(\mathrm{XSSX})$

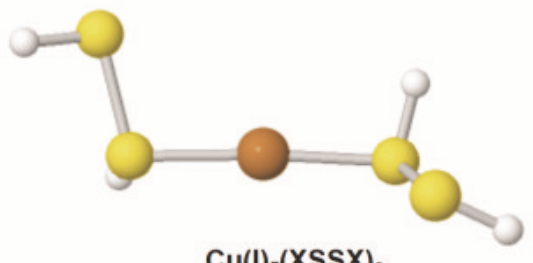

$\mathrm{Cu}(\mathrm{I})-(\mathrm{XSSX})_{2}$

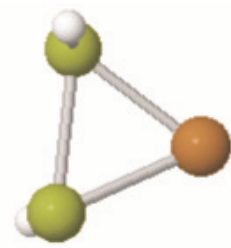

$\mathrm{Cu}(\mathrm{I})-(\mathrm{XSeSeX})$

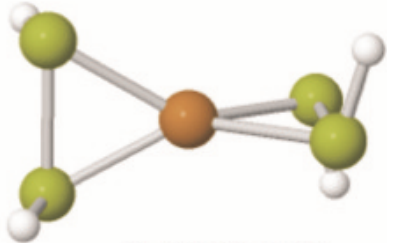

$\mathrm{Cu}(\mathrm{I})-(\mathrm{XSeSeX})_{2}$

Figure 5. Representative optimized structures of $\mathrm{Cu}(\mathrm{I})(\mathrm{XYYX})_{1,2}$ 
Table 4. Interligand bond distances (in $\AA$ ) for $\mathrm{M}(\mathrm{HYYH})_{1,2}$ complexes. Numbers in parenthesis indicate $\mathrm{YY}$ and $\mathrm{YH}$ values in the free base

\begin{tabular}{|c|c|c|c|c|c|c|c|}
\hline \multirow[b]{2}{*}{ Metal } & \multirow[b]{2}{*}{ Compl. } & \multicolumn{3}{|c|}{$\mathrm{Y}-\mathrm{Y}$} & \multicolumn{3}{|c|}{$\mathrm{H}-\mathrm{Y}$} \\
\hline & & $\begin{array}{c}\mathrm{O} \\
(1.451)\end{array}$ & $\begin{array}{c}\mathrm{S} \\
(2.087)\end{array}$ & $\begin{array}{c}\mathrm{Se} \\
(2.360)\end{array}$ & $\begin{array}{c}\mathrm{O} \\
(0.967)\end{array}$ & $\begin{array}{c}\mathrm{S} \\
(1.350)\end{array}$ & $\begin{array}{c}\mathrm{Se} \\
(1.476)\end{array}$ \\
\hline $\mathrm{Ca}^{2+}$ & $1: 1$ & 1.456 & 2.139 & 2.431 & 0.982 & 1.356 & 1.482 \\
\hline $\mathrm{Ca}^{2+}$ & $2: 1$, homo & 1.454 & 2.128 & 2.423 & 0.979 & 1.354 & 1.478 \\
\hline $\mathrm{Ca}^{2+}$ & $2: 1$, het & 1.454 & 2.128 & 2.423 & 0.979 & 1.354 & 1.478 \\
\hline $\mathrm{Cu}^{+}$ & $1: 1$ & 1.454 & 2.192 & 2.498 & 0.973 & 1.352 & 1.478 \\
\hline $\mathrm{Cu}^{+}$ & $2: 1$, homo & 1.455 & 2.106 & 2.450 & 0.973 & 1.352 & 1.475 \\
\hline $\mathrm{Cu}^{+}$ & $2: 1$, het & 1.455 & 2.106 & 2.450 & 0.973 & 1.352 & 1.476 \\
\hline $\mathrm{Li}^{+}$ & $1: 1$ & 1.457 & 2.127 & 1.350 & 0.974 & 2.420 & 1.475 \\
\hline $\mathrm{Li}^{+}$ & $2: 1$, homo & 1.456 & 2.118 & 1.349 & 0.972 & 2.408 & 1.474 \\
\hline $\mathrm{Li}^{+}$ & $2: 1$, het & 1.456 & 2.118 & 1.349 & 0.972 & 2.408 & 1.474 \\
\hline $\mathrm{Zn}^{2+}$ & $1: 1$ & 1.490 & 2.261 & 2.566 & 0.992 & 1.365 & 1.490 \\
\hline $\mathrm{Zn}^{2+}$ & $2: 1$, homo & 1.479 & 2.195 & 2.478 & 0.986 & 1.358 & 1.482 \\
\hline $\mathrm{Zn}^{2+}$ & $2: 1$, het & 1.479 & 2.195 & 2.478 & 0.985 & 1.358 & 1.482 \\
\hline
\end{tabular}

Another point of interest is the analysis of the electronic rearrangement undergone by the base upon metal cation interaction. To illustrate this aspect, we will focus on the complexes containing the hydrogenated ligands, HYYH, whose B3LYP Y-Y and $\mathrm{Y}-\mathrm{H}$ distances are reported in Table 4. Table S-III reports B3LYP and MP2 Y-Y bond lengths for all the complexes considered in this work. From the inspection of these tables, we observe in all the cases a lengthening of the $\mathrm{Y}-\mathrm{Y}$ bonds compared to the free base, although this activation occurs to different extents depending on the nature of the metal cation and the ligands. The metal cations are expected to polarize the basic center lone pairs. This polarizarization would be transmitted to the $\mathrm{Y}-\mathrm{Y}$ and $\mathrm{Y}-\mathrm{H}$ bonds in such a way as to increase their bond lengths. In this respect, the YY smallest activation is observed for the $\mathrm{HOOH}$ complexes with the less polarizable ligands, and to the $\mathrm{Li}^{+}$ or $\mathrm{Ca}^{2+}$-containing complexes, as their bonding is essentially electrostatic. The largest activation is observed for $\mathrm{Zn}(\mathrm{II})(\mathrm{HSeSeH})$, which exhibits a lengthening of the Se-Se and $\mathrm{Se}-\mathrm{H}$ bonds of ca. $9 \%$ and $1 \%$, respectively.

\section{Bonding Trends and AIM Analysis}

In order to investigate the metal-ligand bonding, AIM analyses were carried out for all the complexes with hydrogenated and unimethylated ligands. The measures of the Laplacian, the ellipticity, the electronic energy density, and the population analysis data have been collected in Figures. 6 and 7(a,b). Although the AIM results clearly show that the electron density topology of the complexes generally differs negligibly between the homo- and heterochiral stereoisomers, the results also reveal a number of interesting metal-ligand bonding trends present in the complexes. At the BCP, the magnitude of the total electronic energy density $H\left(r_{\mathrm{c}}\right)$ is typically related to the degree of covalence of the bonding interaction; the more negative $H\left(r_{\mathrm{c}}\right)$ is, the greater the ratio of potential to kinetic energy density, the higher the electron density, and the greater the sharing of electrons between the two atoms. ${ }^{41}$ The low electron densities and positive $H\left(r_{\mathrm{c}}\right)$ at the the BCPs of the metal ligand bonds at the calcium and lithium complexes affirm that these complexes are essentially ionic and that the ligands are strongly polarized. The situation is different for the transition metals $\mathrm{Cu}(\mathrm{I})$ and $\mathrm{Zn}(\mathrm{II})$ : naturally, the strongly negative $H\left(r_{\mathrm{c}}\right)$ values and the bond order data (Figure 7(c)) in these compounds confirm that $\mathrm{Cu}(\mathrm{I})$-chalcogens bonds, followed by $\mathrm{Zn}$ (II)-chalcogen bonds, are the most stable of the four metals studied due to the large charge transfer between the lone pairs of the chalcogen and empty $4 \mathrm{~s}$ orbitals of the metal cation.

This ligand to metal charge transfer in transition metal complexes is also reflected in the net Bader charges calculated on the metal center. An inspection of Figure 7(a) reveals the greater polarization undergone by the ligands upon interaction with $\mathrm{Cu}(\mathrm{I})$ and $\mathrm{Zn}(\mathrm{II})$, whose net charges range from $0.8-0.4$ and from 1.6-0.9 respectively, compared to $\mathrm{Li}(\mathrm{I})$ and $\mathrm{Ca}$ (II) for which net charges in excess of 0.9 and 1.6 were calculated. 


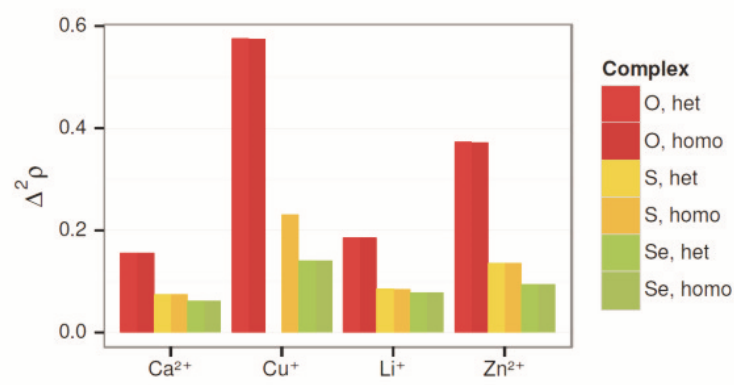

(a) Laplacians, $\nabla^{2} \rho$ for $\mathrm{M}(\mathrm{HYYH})_{2}$

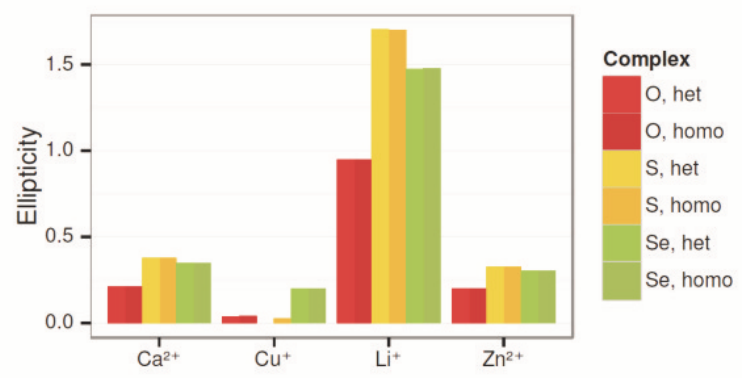

(c) Ellipticities, $\varepsilon$ for $\mathrm{M}(\mathrm{HYYH})_{2}$

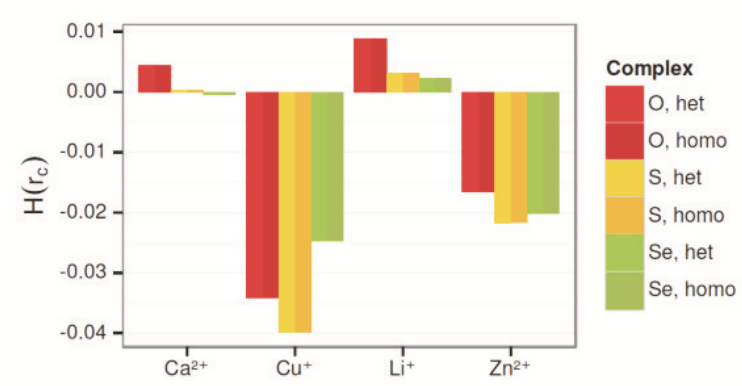

(e) Local electronic energy densities, $H\left(r_{\mathrm{c}}\right)$ for $\mathrm{M}(\mathrm{HYYH})_{2}$
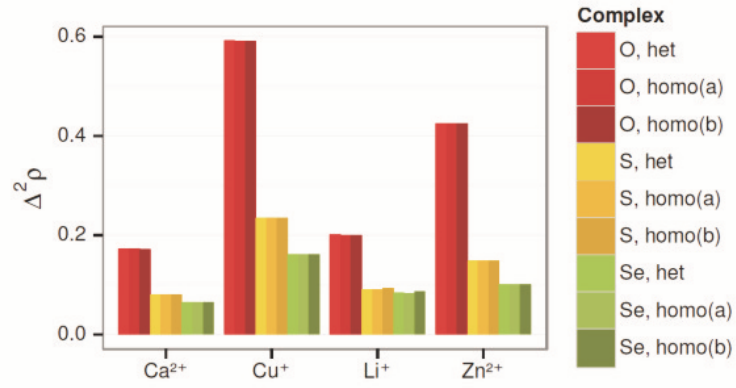

(b) Laplacians, $\nabla^{2} \rho$ for $\mathrm{M}(\mathrm{HYYMe})_{2}$

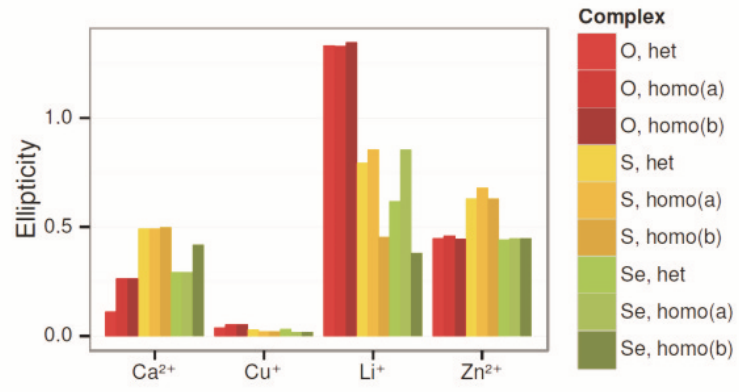

(d) Ellipticities, $\varepsilon$ for $\mathrm{M}(\mathrm{HYYMe})_{2}$

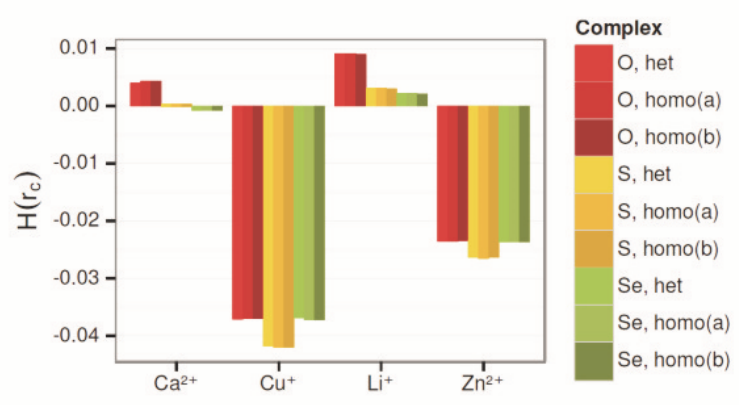

(f) Local electronic energy densities, $H\left(r_{\mathrm{c}}\right)$ for $\mathrm{M}(\mathrm{HYYMe})_{2}$

Figure 6. The averaged Laplacians, ellipticities, and energy densities of the four metal-X bonds in $\mathrm{M}(\mathrm{HYYH}) 2$ (left) and methylsubstituted $\mathrm{M}\left(\mathrm{HYY}\left(\mathrm{CH}_{3}\right)\right)_{2}$ (right) complexes at the metal-ligand BCP. Local electronic energy densities are calculated as the sum between the kinetic and the potential energy densities, $\mathrm{G}+\mathrm{V}$. Heterochiral symmetries include $C_{1}$ and $S_{4}$, homochiral symmetries include $C_{2} a, C_{2} b$, and $D_{2}$.

Interestingly, the charge of metal center, especially for the first-row transition metal, exhibits a large dependency upon the type of chalcogen in the ligands. For instance, the zinc center bound with peroxides has an average calculated charge of 1.6 , but less than 1.0 when bound with selenides. The average charge for the ionic calcium and lithium centers, on the other hand, vary less than $5 \%$ and $2 \%$ respectively along group 16 . (See metal Bader charges in Figure 7(a), bond orders in Figure $7(\mathrm{c})$ ). The relative polarization of the ligands upon metal attachment is also reflected in the charge localized in the chalcogen atoms. Oxygen atoms in peroxides carry a strong negative charge, while sulfur and selenium atoms in sulfides and selenides are slightly positively charged. (See Figure 7(b))

The ellipticity values for the metal-ligand bonds indicate that those of the alkali metals are significantly weaker compared to those formed in complexation with transition metals. With the exception of $\mathrm{Cu}(\mathrm{I})$, calculated bond orders generally follow the trend $\mathrm{O}<\mathrm{S}<\mathrm{Se}$, and $\mathrm{Li}$ $<\mathrm{Ca}<\mathrm{Zn}<\mathrm{Cu}$, inversely related to the bond strain as reflected in the ellipticity values. Ellipticities are also lower for the methyl-substituted ligands than for the hydrogenated ligands, indicating that methylation stabilizes the metal-ligand bonds to an extent due to electron induction and polarization - a trend in agreement with the MP2 and DFT minimum energies of the methylated and hydrogenated structures. (Figure 6(c)) 


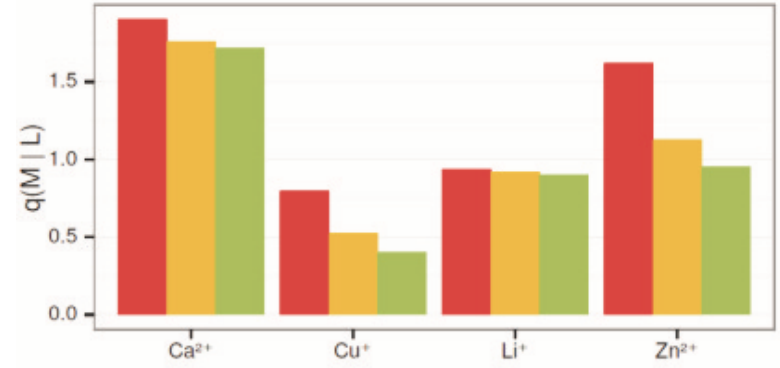

(a) Charge of metal ion

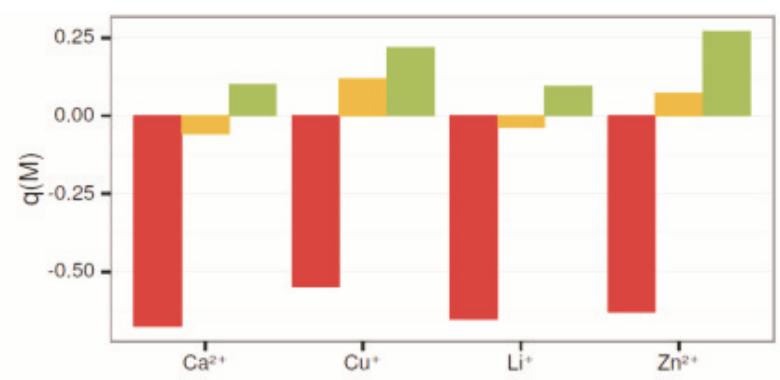

(b) Average charge of chalcogens

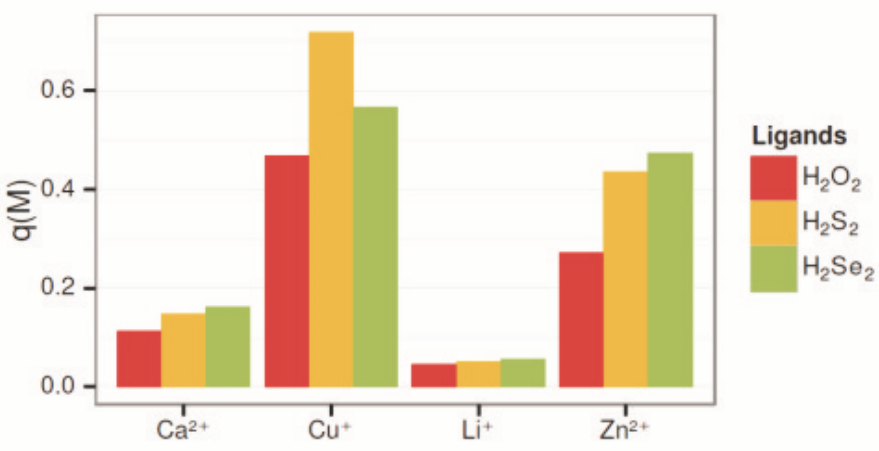

(c) Bond order

Figure 7. Diatomic electron pair contributions from AIM analyses of MP2 optimized M(HYYH $)_{2}$ complexes.

\section{Deprotonation Energies}

From previous DFT and mass spectrometry studies, $\mathrm{Cu}$ (II) has been known to undergo oxidative addition followed by deprotonation when reacting with protic ligands. ${ }^{42}$ The reason for this has been attributed to the second ionization energy of the metal cation being significantly larger than the first ionization energy of the ligand, which has the effect of increasing the acidity of the ligand. Despite the multireference nature of the $\mathrm{Cu}(\mathrm{I})$ and $\mathrm{Cu}(\mathrm{II})$ complexes, we calculated the energy change during the exchange of a proton between $\mathrm{M}(\mathrm{HYYH})_{1,2}$ complexes and a single ligand in order to predict whether the complexes considered in this work

Table 5. Energetics in $\mathrm{kJ} / \mathrm{mol}$ for the proton transfer reaction $\mathrm{M}(\mathrm{HYYH})_{1,2}+\mathrm{HYYH} \rightarrow \mathrm{M}\left(\mathrm{HYY}^{-}\right)+\mathrm{HYYH}_{2}{ }^{+}$at B3LYP/aug-cc-pVTZ level of theory. (2:1) Deprotonation energies correspond to the average for the homo- and the heterochiral complexes

\begin{tabular}{lrrrrrr}
\hline Metal & \multicolumn{2}{c}{$\mathrm{Y}=\mathrm{O}$} & \multicolumn{2}{c}{$\mathrm{Y}=\mathrm{S}$} & \multicolumn{2}{c}{$\mathrm{Y}=\mathrm{Se}$} \\
\hline & $(1: 1)$ & $(2: 1)$ & $(1: 1)$ & $(2: 1)$ & $(1: 1)$ & $(2: 1)$ \\
\hline $\mathrm{Cu}^{2+}$ & -593 & -411 & -533 & -317 & -503 & -294 \\
$\mathrm{Cu}^{+}$ & 220 & 67 & 102 & 185 & 94 & 138 \\
$\mathrm{Zn}^{2+}$ & -453 & -295 & -453 & -316 & -443 & -279 \\
$\mathrm{Li}^{+}$ & 279 & 343 & 167 & 209 & 145 & 187 \\
$\mathrm{Ca}^{2+}$ & -216 & -158 & -315 & -208 & -303 & -208 \\
\hline
\end{tabular}

are stable to the deprotonation reaction $\mathrm{M}(\mathrm{HYYH})_{1,2}+$ $\mathrm{HYYH} \rightarrow \mathrm{M}\left(\mathrm{HYY}^{-}\right)+\mathrm{HYYH}_{2}{ }^{+}$. For each of the B3LYP/aug-cc-pVTZ optimized M(HYYH) $)_{1,2}$ structures, a proton was removed from the ligand and the resulting complex was re-optimized at the same level of theory. Deprotonation energies for $\mathrm{M}(\mathrm{HYYH})_{1,2}$ complexes have been collected in Table 5. The energies presented for the bisligand complexes correspond to the average for the homo- and heterochiral complexes, as negligible difference were found between the two. As expected from the comparison of the ionization potentials of $\mathrm{Cu}^{+}(20.29 \mathrm{eV})$ and $\mathrm{Cu}(7.7 \mathrm{eV})$ and the ligands $\mathrm{H}_{2} \mathrm{O}_{2}(10.58 \mathrm{eV}),{ }^{43} \mathrm{H}_{2} \mathrm{~S}_{2}(9.3 \mathrm{eV})$ and $\mathrm{H}_{2} \mathrm{Se}_{2}$ $(8.53 \mathrm{eV}),{ }^{44}$ all the $\mathrm{Cu}^{+}$complexes considered were found to be stable to deprotonation processes, while the opposite was observed for their $\mathrm{Cu}^{2+}$ analogues. Interestingly, the ionization energies of $\mathrm{Ca}^{+}(11.87 \mathrm{eV})$ and $\mathrm{Zn}^{+}(17.96 \mathrm{eV})^{43}$ also well above those measured or calculated for the ligands, translated into exothermicities that range between 150 and $450 \mathrm{~kJ} / \mathrm{mol}$. An endothermic energetic balance for the same reaction is however observed for the metal complexes with the metal with the lowest ionization energy $\mathrm{Li}^{+}(5.4 \mathrm{eV})$.

\section{Transition States}

At the B3LYP/aug-cc-pVTZ level, we have identified two possible pathways for the racemization of the $1: 1$ and 2:1 homo- and heterochiral HYYH complexes. 


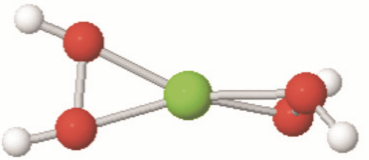

(a) Cis

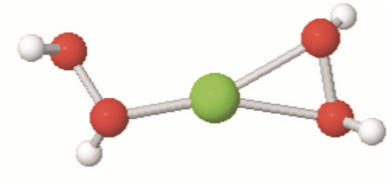

(b) Trans

Figure 8. The two types of located transition state structures in the homo-heterochiral racemization pathway.

Figure 8 shows the two kinds of transition states found for ML2 complexes, i.e. cis and trans, differing in the disposition of the $\mathrm{H}$ in the ligand undergoing isomerization. Interestingly, in the cis transition state structure the metal cation remains bonded simultaneously to both chalcogens of each ligand, whereas in the trans structure the metal binds preferentially to one chalcogen of the bridge. These two possible transition state structures are in agreement with those found in previous studies for similar model systems. ${ }^{28,29,45}$ Since the monoligand $\mathrm{Cu}(\mathrm{I})(\mathrm{HSSH})$ complex yielded both $c$ is and trans transition structures, we have run IRC calculations on both structures to confirm that both relax to the two expected isomers in the forward and backward directions (see Figure 9). The preferred transition pathway displays a dependency upon the nature of the bonding - for the ionically-bonded alkali and alkaline earth metals $\mathrm{Li}^{+}$and $\mathrm{Ca}^{2+}$, interconversion between the homo- and heterochiral configurations occurs by way of an intermediate cis geometry in which the former stereocenter becomes planar, and hence, achiral. The transition metal complexes of $\mathrm{Cu}(\mathrm{I})$ and $\mathrm{Zn}(\mathrm{II})$, by contrast, tended to proceed via a broken trans intermediate, reminiscent of the optimized structures for the $\mathrm{Cu}(\mathrm{I})$ complexes, recall Figure 5. Though cis intermediates were located for several $\mathrm{Cu}$ (I) and $\mathrm{Zn}$ (II) complexes, they were in all cases either second-order transition states or higher in energy than their trans

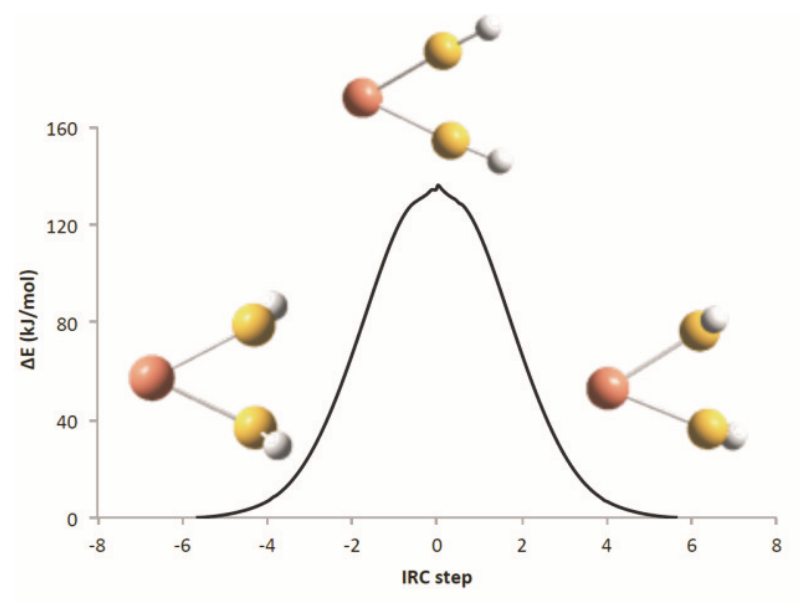

(a) Cis pathway

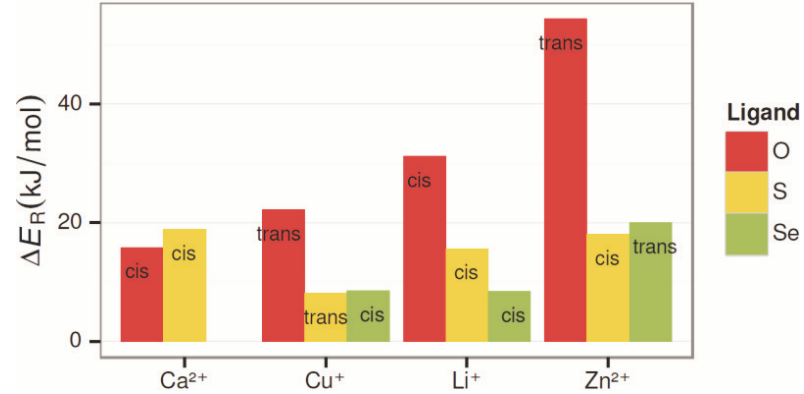

Figure 10. The racemization barriers $\left(E_{\mathrm{R}}\right.$, in $\left.\mathrm{kJ} / \mathrm{mol}\right)$ between homo-/heterochiral $\mathrm{M}(\mathrm{HYYH})_{2}$ dimers. Labels designate the transition state as either cis or trans (see Figure 8).

counterparts. The location of trans transition states for the $\mathrm{Zn}(\mathrm{II})$ complexes suggests that for the ligands in this work, $\mathrm{Zn}$ (II) may also have a tendency for two- rather than four-coordination, much like $\mathrm{Cu}(\mathrm{I})$.

Figure 10 shows the racemization barriers $E_{\mathrm{R}}$, calculated as the energy difference between the heterochiral structure and the located transition state structure for $\mathrm{M}(\mathrm{HYYH})_{2}$ complexes. The racemization barriers for the ML2 structures were in all cases less than $80 \mathrm{~kJ} / \mathrm{mol}$, well below the bond disassociation energies of the relatively weak $\mathrm{O}-\mathrm{O}$ bonds $(\mathrm{BDE}=209 \mathrm{~kJ} / \mathrm{mol})^{46}$ and $\mathrm{S}-\mathrm{S}$ bonds $(\mathrm{BDE}=250 \mathrm{~kJ} / \mathrm{mol})^{47}$ in the gas phase. Interconversion between the two stereoisomers would therefore occur at a noticeable rate at room temperatures.

\section{CONCLUSIONS AND OUTLOOK}

In this theoretical study, we have obtained the homochiral and heterochiral minimal structures of $\mathrm{M}(\mathrm{XYYX})_{2}$ dimers at the B3LYP and MP2/aug-ccpVTZ level of theory. In total, 150 structures have been considered in this work: 45 monomers, 60 homochiral dimers and 45 heterochiral dimers. However, $\mathrm{Cu}(\mathrm{II})$

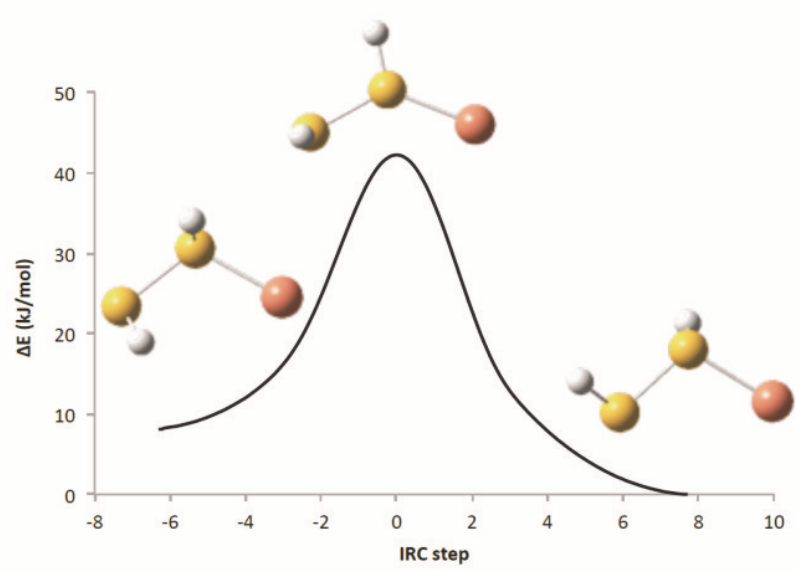

(b) Trans pathway

Figure 9. Isomerization pathway of the isolated $\mathrm{Cu}(\mathrm{I})(\mathrm{HSSH})$ monomer. 
complexes were excluded from the stability and bond discussion based on the multiconfigurational nature of the wavefunction of its complexes. In agreement with the previous results for complexes with axial chirality in the gas phase, the heterochiral isomers were in the majority of cases lower in energy than their homochiral counterparts. ${ }^{28,29}$ The small but consistent differences in energy may indeed serve as grounds for chiral distinction.

One of the largest sources of errors in this study appears to be the monodeterminant description of the copper complexes, for which static correlation plays a significant role. The $\mathrm{Cu}(\mathrm{I})$ series of complexes prove themselves an exception to the many trends observed in this study due to their slight degree of multi-reference character. From the relative homo-heterochiral stabilities, we found slightly different behaviors of $\mathrm{Cu}(\mathrm{I})$ at the DFT and MP2 levels of theory, indicating the difficulty of correctly modeling the $\mathrm{Cu}(\mathrm{I})$ bonding. Short of a thorough CASSCF/CASPT2 multireference investigation, improvements to the DFT results in this study would include an assessment of different functionals, in particular, the newest classes of functionals including M05 and M06L, in order to observe whether they mitigate the error in the thermochemical DFT data for copper. ${ }^{48,49}$

Despite the multireference character of the copper species, the minimal energy structures and the AIM analysis of the study unequivocally show that the transition metals $\mathrm{Cu}(\mathrm{I})$ and $\mathrm{Zn}^{2+}$ distinctly exhibited a greater potential for chiral distinction than the calcium and lithium ions, whose interactions with the ligand were predominantly ionic. $\mathrm{Cu}(\mathrm{I})$, followed by $\mathrm{Zn}^{2+}$, remain the most preferred metals for binding with the chalcogenic ligands - a conclusion consistent with the abundance of transition metal complexes and the special importance that copper and zinc ions reserve in biological systems. Hence, extrapolating our results for larger model systems, we speculate that copper and zinc ions would be able to exhibit a noticeable preference for the heterochiral isomer, particularly when complexing with larger ligands.

Considering that the energetic differences between the majority of the isomer pairs in our study were under $1 \mathrm{~kJ} / \mathrm{mol}$, we conclude that neither the change in the character of the metal nor the nature of the substrate dramatically affect the relative stabilities of the homoand heterochiral dimers. Our study has shown, however, that a handful of indicators such as the dihedral angles and relative energy differences indeed correlate with the chirality of the complex. We note that the trends observed for the enantiomer pairs are highly sensitive to the nature of the metal and chalcogen of the complex, necessitating a basis-by-basis consideration of the systems.
Supplementary Materials. - Supporting informations to the paper are enclosed to the electronic version of the article. These data can be found on the website of Croatica Chemica Acta (http://public.carnet.hr/ccacaa).

Acknowledgements. This work has been partially supported by the Ministerio de Economía y Competitividad (Project No. CTQ2012-35513-C02). KJC acknowledges support from the Erasmus Mundus program of the European Union. This work was carried out with the generous allocation of computing time from the Centro de Computación Científica, UAM.

\section{REFERENCES}

1. C. Pérollier, S. Constant, J. J. Jodry, G. Bernardinelli, and J. Lacour, Chem. Comm. (2003) 2014-2015.

2. W. Tao, D. Zhang, E. N. Nikolaev, and R. G. Cooks, J. Am. Chem. Soc. 122 (2000) 10598-10609.

3. J. J. Jodry, R. Frantz, and J. Lacour, Inorg. Chem. 43 (2004) 3329-3331.

4. S. Zang, Y. Su, Y. Li, Z. Ni, and Q. Meng, Inorg. Chem. 45 (2006) 174-180

5. V. Humblot, S. Barlow, and R. Raval, Prog. Surf. Sci. 76 (2004) 1-19.

6. L. Wu, E. C. Meurer, and R. G. Cooks, Anal. Chem. 76 (2004) $663-671$.

7. G. Smith and J. A. Leary, J. Am. Chem. Soc. 120 (1998) 13046-13056.

8. W. A. Tao, D. Zhang, F. Wang, P. D. Thomas, and R. G. Cooks, Anal. Chem. 71 (1999) 4427-4429.

9. W. A. Tao, D. Zhang, E. N. Nikolaev, and R. G. Cooks, J. Am. Chem. Soc. 122 (2000) 10598-10609.

10. R. G. Cooks, J. S. Patrick, T. Kotiaho, and S. A. McLuckey, Mass Spectrom. Rev. 13 (1994) 287-339.

11. A. Paladini, C. Calcagni, T. Di Palma, M. Speranza, A. Laganà, G. Fago, A. Filippi et al., Chirality 13 (2001) 707-711.

12. Y. Tapuhi, N. Miller, and B. L. Karger, J. Chromatogr. A 205 (1981) 325-337.

13. W. Lindner, J. LePage, G. Davies, D. Seitz, and B. Karger, J. Chromatogr. A 185 (1979) 323-343.

14. H.-Y. Wang and E. Friedman, Psychopharmacology 99 (1989) 213-218.

15. K. Cheng, S. Creacy, and J. Larner, Mol. Cell. Biochem. 56 (1983) 183-189.

16. J. Rotruck, A. Pope, H. Ganther, A. Swanson, D. G. Hafeman, and W. Hoekstra, Science 179 (1973) 588-590.

17. Y. Jeanvoine and R. Spezia, J. Phys. Chem. A 113 (2009) 7878-7887.

18. I. Alkorta, O. Picazo, and J. Elguero, J. Phys. Chem. A 109 (2005) 9573-9577.

19. I. Rozas, I. Alkorta, and J. Elguero, J. Phys. Chem. A 110 (2006) 13310-13316.

20. K. Zborowski, I. Alkorta, and J. Elguero, J. Phys. Chem. A 110 (2006) 7247-7252.

21. M. Elango, R. Parthasarathi, V. Subramanian, C. Ramachan-dran, and N. Sathyamurthy, J. Phys. Chem. A 110 (2006) 6294-6300.

22. I. Alkorta, F. Blanco, J. Elguero, and D. Schröder, TetrahedronAsymmetr. 21 (2010) 962-968.

23. O. Picazo, I. Alkorta, J. Elguero, M. R. Sundberg, and J. Valo, Eur. J. Inorg. Chem. 2007 (2007) 324-332.

24. O. Picazo, I. Alkorta, J. Elguero, and M. R. Sundberg, Inorg. Chem. Commun. 9 (2006) 712-715.

25. O. Picazo, I. Alkorta, J. Elguero, M. Sundberg, J. Valo, and K. Zborowski, Struct. Chem. 20 (2009) 557-563. 
26. I. Alkorta and J. Elguero, J. Chem. Phys. 117 (2002) 6463-6468.

27. I. Alkorta, K. Zborowski, and J. Elguero, Chem. Phys. Lett. 427 (2006) 289-294.

28. I. Alkorta, J. Elguero, P. F. Provasi, and M. B. Ferraro, J. Phys. Chem. A 115 (2011) 7805-7810.

29. G. Sánchez-Sanz, C. Trujillo, I. Alkorta, and J. Elguero, ChemPhysChem 13 (2012) 496-503.

30. T. H. Dunning Jr, J. Chem. Phys. 90 (1989) 1007.

31. I. Corral and M. Yáñez, Phys. Chem. Chem. Phys. 13 (2011) 14848-14864.

32. M. A. Iron, M. Oren, and J. M. Martin, Mol. Phys. 101 (2003) 1345-1361.

33. T. J. Lee and P. R. Taylor, Int. J. Quantum Chem. 36 (1989) 199-207.

34. M. J. Frisch, G. W. Trucks, H. B. Schlegel, G. E. Scuseria, M. A. Robb, J. R. Cheeseman, G. Scalmaniet al., Gaussian 09, Revision B.01 (2009).

35. T. A. Keith, Aimall, version 13.05.06, TK Gristmill Software (2013).

36. J.-M. Ducéré, A. Goursot, and D. Berthomieu, J. Phys. Chem. A 109 (2005) 400-408.

37. A. Luna, M. Alcamí, O. Mó, and M. Yáñez, Chem. Phys. Lett.
320 (2000) 129-138

38. Y. Jeanvoine and R. Spezia, J. Phys. Chem. A 113 (2009) 7878-7887.

39. M. Pavelka and J. V. Burda, Chem. Phys. 312 (2005) 193-204.

40. T. N. Sorrell and D. L. Jameson, J. Am. Chem. Soc. 105 (1983) 6013-6018.

41. G. V. Gibbs, M. Spackman, D. Jayatilaka, K. M. Rosso, and D. F. Cox, J. Phys. Chem. A 110 (2006) 12259-12266.

42. T. Shi, K. Siu, and A. C. Hopkinson, Int. J. Mass Spectrom. 255 (2006) 251-264

43. H. Rosenstock, K. Draxl, B. Steiner, and J. Herron, Ion Energetics Data, NIST ChemistryWebBook (National Institute of Standards and Technology).

44. Calculated in this work.

45. I. Alkorta, K. Zborowski, J. Elguero, and M. Solimannejad, J. Phys. Chem. A 110 (2006) 10279-10286.

46. R. D. Bach, P. Y. Ayala, and H. Schlegel, J. Am. Chem. Soc. 118 (1996) 12758-12765.

47. B. S. Jursic, Int. J. Quantum Chem. 62 (1997) 291-296.

48. Y. Zhao and D. G. Truhlar, Acc. Chem. Res. 41 (2008) 157-167.

49. Y. Zhao and D. G. Truhlar, Theor. Chem. Acc. 120 (2008) $215-241$. 


\title{
Can transition metals and group II mono- and
} dications discriminate between homo- and heterochiral $X Y Y X^{\prime}$ dimers $\left(X, X^{\prime}=H, M e ;\right.$

$$
\mathrm{Y}=\mathrm{O}, \mathrm{S}, \mathrm{Se}) ?
$$

\author{
Kathy J. Chen, ${ }^{\dagger}$ Otilia Mó, ${ }^{\ddagger}$ Manuel Yáñez, ${ }^{\ddagger}$ and Inés Corral ${ }^{*, \ddagger}$ \\ Laboratoire CEISAM - UMR CNRS 6230, Université de Nantes, 2 Rue de la Houssinière, \\ BP 92208, 44322 Nantes Cedex 3, France, and Departamento de Química, Universidad \\ Autónoma de Madrid, 28049, Cantoblanco, Madrid, Spain \\ E-mail: ines.corral@uam.es
}

*To whom correspondence should be addressed

${ }^{\dagger}$ CEISAM, Nantes

${ }_{\ddagger}^{\ddagger}$ Departamento de Química, Universidad Autónoma de Madrid, 28049, Cantoblanco, Madrid, Spain 
Table S-I: Dihedral angles (deg) of $\mathrm{M}(\mathrm{XYYX})_{2}$ complexes optimized at B3LYP and MP2/aug-cc-pVTZ.

\begin{tabular}{|c|c|c|c|c|c|c|c|c|c|}
\hline \multirow[b]{2}{*}{ Metal } & \multirow[b]{2}{*}{ Substituent } & \multirow[b]{2}{*}{ Type } & \multirow[b]{2}{*}{ Symmetry } & \multicolumn{3}{|c|}{ B3LYP } & \multicolumn{3}{|c|}{ MP2 } \\
\hline & & & & $\mathrm{O}$ & $\mathrm{S}$ & $\mathrm{Se}$ & $\mathrm{O}$ & $\mathrm{S}$ & $\mathrm{Se}$ \\
\hline $\mathrm{Ca}^{2+}$ & $\mathrm{H}$ & het & $\mathrm{S}_{4}$ & 90.00 & 90.00 & 89.97 & 90.00 & 90.00 & 89.97 \\
\hline $\mathrm{Ca}^{2+}$ & methyl & het & $\mathrm{C}_{1}$ & 88.16 & 89.05 & 54.25 & 88.27 & 89.20 & 88.44 \\
\hline $\mathrm{Ca}^{2+}$ & dimethyl & het & $\mathrm{S}_{4}$ & 90.00 & 90.00 & 89.96 & 90.00 & 90.00 & 89.97 \\
\hline $\mathrm{Cu}^{+}$ & $\mathrm{H}$ & het & $\mathrm{S}_{4}$ & 46.95 & 72.54 & 90.00 & 72.16 & 81.07 & 90.00 \\
\hline $\mathrm{Cu}^{+}$ & methyl & het & $\mathrm{C}_{1}$ & 86.77 & 56.57 & 68.67 & 81.47 & 49.98 & 89.99 \\
\hline $\mathrm{Cu}^{+}$ & dimethyl & het & $\mathrm{S}_{4}$ & 86.13 & 75.39 & 90.00 & 84.76 & 64.71 & 90.00 \\
\hline $\mathrm{Li}^{+}$ & $\mathrm{H}$ & het & $\mathrm{S}_{4}$ & 90.00 & 90.00 & 89.99 & 90.00 & 90.00 & 89.99 \\
\hline $\mathrm{Li}^{+}$ & methyl & het & $\mathrm{C}_{1}$ & 88.44 & 89.37 & 87.41 & 89.99 & 89.68 & 89.08 \\
\hline $\mathrm{Li}^{+}$ & dimethyl & het & $\mathrm{S}_{4}$ & 90.00 & 90.00 & 89.99 & 90.00 & 90.00 & 90.00 \\
\hline $\mathrm{Zn}^{2+}$ & $\mathrm{H}$ & het & $\mathrm{S}_{4}$ & 90.00 & 90.00 & 90.00 & 90.00 & 90.00 & 90.00 \\
\hline $\mathrm{Zn}^{2+}$ & methyl & het & $\mathrm{C}_{1}$ & 88.21 & 89.87 & 89.50 & 89.52 & 89.71 & 89.34 \\
\hline $\mathrm{Zn}^{2+}$ & dimethyl & het & $\mathrm{S}_{4}$ & 90.00 & 90.00 & 90.00 & 90.00 & 90.00 & 90.00 \\
\hline $\mathrm{Ca}^{2+}$ & $\mathrm{H}$ & homo & $\mathrm{D}_{2}$ & 71.45 & 64.94 & 78.41 & 70.94 & 64.80 & 69.15 \\
\hline $\mathrm{Ca}^{2+}$ & methyl & homo & $\mathrm{C}_{2} \mathrm{a}$ & 64.76 & 63.09 & 74.82 & 74.12 & 61.72 & 66.48 \\
\hline $\mathrm{Ca}^{2+}$ & methyl & homo & $\mathrm{C}_{2} \mathrm{~b}$ & 70.33 & 64.35 & 69.41 & 79.65 & 61.26 & 60.58 \\
\hline $\mathrm{Ca}^{2+}$ & dimethyl & homo & $\mathrm{D}_{2}$ & 62.96 & 63.73 & 61.70 & 75.54 & 60.99 & 59.69 \\
\hline $\mathrm{Cu}^{+}$ & $\mathrm{H}$ & homo & $\mathrm{D}_{2}$ & 56.14 & 63.45 & 74.94 & 89.55 & 56.28 & 76.19 \\
\hline $\mathrm{Cu}^{+}$ & methyl & homo & $\mathrm{C}_{2} \mathrm{a}$ & 72.22 & 69.13 & 74.09 & 86.27 & 78.19 & 85.89 \\
\hline $\mathrm{Cu}^{+}$ & methyl & homo & $\mathrm{C}_{2} \mathrm{~b}$ & 68.73 & 64.38 & 74.30 & 69.91 & 78.16 & 85.83 \\
\hline $\mathrm{Cu}^{+}$ & dimethyl & homo & $\mathrm{D}_{2}$ & 72.10 & 77.25 & 72.65 & 63.26 & 76.08 & 82.45 \\
\hline $\mathrm{Li}^{+}$ & $\mathrm{H}$ & homo & $\mathrm{D}_{2}$ & 87.28 & 64.01 & 71.46 & 87.62 & 61.73 & 66.51 \\
\hline $\mathrm{Li}^{+}$ & methyl & homo & $\mathrm{C}_{2} \mathrm{a}$ & 88.70 & 64.48 & 66.35 & 88.63 & 62.43 & 66.60 \\
\hline $\mathrm{Li}^{+}$ & methyl & homo & $\mathrm{C}_{2} \mathrm{~b}$ & 87.99 & 61.94 & 64.12 & 86.90 & 66.82 & 71.08 \\
\hline $\mathrm{Li}^{+}$ & dimethyl & homo & $\mathrm{D}_{2}$ & 89.41 & 63.63 & 59.39 & 81.90 & 62.77 & 64.81 \\
\hline $\mathrm{Zn}^{2+}$ & $\mathrm{H}$ & homo & $\mathrm{D}_{2}$ & 73.43 & 78.77 & 82.43 & 74.32 & 79.16 & 82.69 \\
\hline $\mathrm{Zn}^{2+}$ & methyl & homo & $\mathrm{C}_{2} \mathrm{a}$ & 72.47 & 74.91 & 78.93 & 75.88 & 77.79 & 82.31 \\
\hline $\mathrm{Zn}^{2+}$ & methyl & homo & $\mathrm{C}_{2} \mathrm{~b}$ & 74.78 & 73.62 & 78.44 & 74.84 & 77.01 & 82.22 \\
\hline $\mathrm{Zn}^{2+}$ & dimethyl & homo & $\mathrm{D}_{2}$ & 73.86 & 70.46 & 74.89 & 77.15 & 76.33 & 82.88 \\
\hline
\end{tabular}


Table S-II: Average metal-ligand bond lengths $(\AA)$ of $\mathrm{M}(\mathrm{XYYX})_{2}$ complexes optimized at B3LYP and MP2/aug-cc-pVTZ. Asterisks indicate M-Y bond lengths reported for two-coordinated complexes.

\begin{tabular}{|c|c|c|c|c|c|c|c|c|}
\hline \multirow[b]{2}{*}{ Metal } & \multirow[b]{2}{*}{ Complex } & \multirow[b]{2}{*}{ Substituent } & \multicolumn{3}{|c|}{ B3LYP } & \multicolumn{3}{|c|}{ MP2 } \\
\hline & & & $\mathrm{O}$ & $\mathrm{S}$ & $\mathrm{Se}$ & $\mathrm{O}$ & S & Se \\
\hline $\mathrm{Ca}^{2+}$ & homo, $\mathrm{C}_{2} \mathrm{a}$ & methyl & 2.391 & 2.939 & 3.010 & 2.426 & 2.901 & 3.020 \\
\hline $\mathrm{Ca}^{2+}$ & homo, $\mathrm{C}_{2} \mathrm{~b}$ & methyl & 2.391 & 2.940 & 3.010 & 2.426 & 2.901 & 3.020 \\
\hline $\mathrm{Ca}^{2+}$ & homo, $\mathrm{D}_{2}$ & dimethyl & 2.372 & 2.915 & 2.987 & 2.405 & 2.880 & 3.001 \\
\hline $\mathrm{Ca}^{2+}$ & homo, $\mathrm{D}_{2}$ & $\mathrm{H}$ & 2.422 & 2.972 & 3.038 & 2.457 & 2.930 & 3.046 \\
\hline $\mathrm{Cu}^{+}$ & homo, $\mathrm{C}_{2} \mathrm{a}$ & methyl & 2.198 & 2.276 & 2.327 & 2.279 & 2.695 & 2.780 \\
\hline $\mathrm{Cu}^{+}$ & homo, $\mathrm{C}_{2} \mathrm{~b}$ & methyl & 2.250 & 2.275 & 2.328 & 2.289 & 2.695 & 2.780 \\
\hline $\mathrm{Cu}^{+}$ & homo, $\mathrm{D}_{2}$ & dimethyl & 2.179 & 2.271 & 2.324 & 2.263 & 2.674 & 2.342 \\
\hline $\mathrm{Cu}^{+}$ & homo, $\mathrm{D}_{2}$ & $\mathrm{H}$ & 2.269 & 2.266 & 2.331 & 2.303 & 2.731 & 2.359 \\
\hline $\mathrm{Li}^{+}$ & homo, $\mathrm{C}_{2} \mathrm{a}$ & methyl & 1.974 & 2.528 & 2.517 & 1.990 & 2.502 & 2.590 \\
\hline $\mathrm{Li}^{+}$ & homo, $\mathrm{C}_{2} \mathrm{~b}$ & methyl & 1.974 & 2.527 & 2.548 & 1.990 & 2.510 & 2.611 \\
\hline $\mathrm{Li}^{+}$ & homo, $\mathrm{D}_{2}$ & dimethyl & 1.963 & 2.509 & 2.538 & 1.976 & 2.488 & 2.577 \\
\hline $\mathrm{Li}^{+}$ & homo, $\mathrm{D}_{2}$ & $\mathrm{H}$ & 1.989 & 2.541 & 2.562 & 2.008 & 2.515 & 2.602 \\
\hline $\mathrm{Zn}^{2+}$ & homo, $\mathrm{C}_{2} \mathrm{a}$ & methyl & 2.002 & 2.403 & 2.442 & 2.006 & 2.361 & 2.461 \\
\hline $\mathrm{Zn}^{2+}$ & homo, $\mathrm{C}_{2} \mathrm{~b}$ & methyl & 2.002 & 2.402 & 2.444 & 2.006 & 2.360 & 2.460 \\
\hline $\mathrm{Zn}^{2+}$ & homo, $D_{2}$ & dimethyl & 1.989 & 2.385 & 2.428 & 1.989 & 2.345 & 2.447 \\
\hline $\mathrm{Zn}^{2+}$ & homo, $\mathrm{D}_{2}$ & $\mathrm{H}$ & 2.022 & 2.408 & 2.452 & 2.022 & 2.368 & 2.471 \\
\hline $\mathrm{Ca}^{2+}$ & hetero, $\mathrm{C}_{1}$ & methyl & 2.390 & 2.940 & 3.010 & 2.425 & 2.901 & 3.006 \\
\hline $\mathrm{Ca}^{2+}$ & hetero, $\mathrm{S}_{4}$ & dimethy & 2.372 & 2.915 & 2.988 & 2.405 & 2.880 & 3.001 \\
\hline $\mathrm{Ca}^{2+}$ & hetero, $\mathrm{S}_{4}$ & $\mathrm{H}$ & 2.422 & 2.973 & 3.038 & 2.457 & 2.930 & 3.046 \\
\hline $\mathrm{Cu}^{+}$ & hetero, $\mathrm{C}_{1}$ & methyl & 2.224 & 2.269 & 2.325 & 2.284 & 2.703 & 2.838 \\
\hline $\mathrm{Cu}^{+}$ & hetero, $\mathrm{S}_{4}$ & dimethyl & 2.210 & 2.266 & 2.319 & 2.269 & 2.685 & 2.341 \\
\hline $\mathrm{Cu}^{+}$ & hetero, $\mathrm{S}_{4}$ & $\mathrm{H}$ & 2.236 & 2.263 & 2.330 & 2.307 & 2.730 & 2.359 \\
\hline $\mathrm{Li}^{+}$ & hetero, $\mathrm{C}_{1}$ & methyl & 1.971 & 2.526 & 2.515 & 1.989 & 2.501 & 2.586 \\
\hline $\mathrm{Li}^{+}$ & hetero, $\mathrm{S}_{4}$ & dimethyl & 1.959 & 2.508 & 2.498 & 1.974 & 2.487 & 2.575 \\
\hline $\mathrm{Li}^{+}$ & hetero, $\mathrm{S}_{4}$ & $\mathrm{H}$ & 1.988 & 2.540 & 2.537 & 2.006 & 2.515 & 2.601 \\
\hline $\mathrm{Zn}^{2+}$ & hetero, $\mathrm{C}_{1}$ & methyl & 2.001 & 2.399 & 2.439 & 2.006 & 2.360 & 2.460 \\
\hline $\mathrm{Zn}^{2+}$ & hetero, $\mathrm{S}_{4}$ & dimethy & 1.988 & 2.381 & 2.421 & 1.989 & 2.344 & 2.446 \\
\hline $\mathrm{Zn}^{2+}$ & hetero, $\mathrm{S}_{4}$ & $\mathrm{H}$ & 2.023 & 2.406 & 2.451 & 2.021 & 2.368 & 2.471 \\
\hline
\end{tabular}


Table S-III: Y-Y bond lengths of $\mathrm{M}(\mathrm{XYYX})_{1,2}$ complexes in Angstroms at the B3LYP and MP2 levels of theory. For the dimers, Y-Y distances have been reported as an average over both ligands.

\begin{tabular}{|c|c|c|c|c|c|c|c|c|c|}
\hline \multirow[b]{2}{*}{ Metal } & \multirow[b]{2}{*}{ Substitution } & \multirow[b]{2}{*}{ Complexation } & \multirow[b]{2}{*}{ Symm./Chiral. } & \multicolumn{3}{|c|}{ B3LYP } & \multicolumn{3}{|c|}{ MP2 } \\
\hline & & & & $\mathrm{O}$ & $\mathrm{S}$ & Se & $\mathrm{O}$ & $\mathrm{S}$ & $\mathrm{Se}$ \\
\hline $\mathrm{Ca}^{2+}$ & $\mathrm{H}$ & $(1: 1)$ & $\mathrm{C}_{2}$ & 1.4276 & 2.1127 & 2.3871 & 1.4562 & 2.1388 & 2.4306 \\
\hline $\mathrm{Ca}^{2+}$ & $\mathrm{H}$ & $(2: 1)$ & het, $\mathrm{S}_{4}$ & 1.4448 & 2.1054 & 2.3784 & 1.4540 & 2.1284 & 2.4230 \\
\hline $\mathrm{Ca}^{2+}$ & $\mathrm{H}$ & $(2: 1)$ & homo, $\mathrm{D}_{2}$ & 1.4448 & 2.1053 & 2.3784 & 1.4541 & 2.1284 & 2.4231 \\
\hline $\mathrm{Ca}^{2+}$ & methyl & $(1: 1)$ & $\mathrm{C}_{1}$ & 1.4261 & 2.0985 & 2.3719 & 1.4734 & 2.1251 & 2.4213 \\
\hline $\mathrm{Ca}^{2+}$ & methyl & $(2: 1)$ & het, $\mathrm{C}_{1}$ & 1.4509 & 2.0911 & 2.3611 & 1.4693 & 2.1165 & 2.4086 \\
\hline $\mathrm{Ca}^{2+}$ & methyl & $(2: 1)$ & homo, $\mathrm{C}_{2} \mathrm{a}$ & 1.4509 & 2.0911 & 2.3622 & 1.4694 & 2.1163 & 2.4103 \\
\hline $\mathrm{Ca}^{2+}$ & methyl & $(2: 1)$ & homo, $\mathrm{C}_{2} \mathrm{~b}$ & 1.4509 & 2.0912 & 2.3621 & 1.4693 & 2.1168 & 2.4102 \\
\hline $\mathrm{Ca}^{2+}$ & dimethyl & $(1: 1)$ & $\mathrm{C}_{2}$ & 1.4264 & 2.0850 & 2.3556 & 1.4934 & 2.1133 & 2.4079 \\
\hline $\mathrm{Ca}^{2+}$ & dimethyl & $(2: 1)$ & het, $\mathrm{S}_{4}$ & 1.4589 & 2.0775 & 2.3455 & 1.4837 & 2.1038 & 2.3953 \\
\hline $\mathrm{Ca}^{2+}$ & dimethyl & $(2: 1)$ & homo, $\mathrm{D}_{2}$ & 1.4588 & 2.0772 & 2.3452 & 1.4840 & 2.1039 & 2.3946 \\
\hline $\mathrm{Cu}^{+}$ & $\mathrm{H}$ & $(1: 1)$ & $\mathrm{C}_{2}$ & 1.4548 & 2.1562 & 2.4357 & 1.4541 & 2.1917 & 2.4984 \\
\hline $\mathrm{Cu}^{+}$ & $\mathrm{H}$ & $(2: 1)$ & het, $\mathrm{S}_{4}$ & 1.4545 & 2.0830 & 2.4091 & 1.4546 & 2.1058 & 2.4496 \\
\hline $\mathrm{Cu}^{+}$ & $\mathrm{H}$ & $(2: 1)$ & homo, $\mathrm{D}_{2}$ & 1.4550 & 2.0830 & 2.4102 & 1.4547 & 2.1057 & 2.4497 \\
\hline $\mathrm{Cu}^{+}$ & methyl & $(1: 1)$ & $\mathrm{C}_{1}$ & 1.4580 & 2.1424 & 2.4229 & 1.4547 & 2.1716 & 2.4871 \\
\hline $\mathrm{Cu}^{+}$ & methyl & $(2: 1)$ & het, $\mathrm{C}_{1}$ & 1.4615 & 2.0728 & 2.3308 & 1.4642 & 2.0967 & 2.3760 \\
\hline $\mathrm{Cu}^{+}$ & methyl & $(2: 1)$ & homo, $\mathrm{C}_{2} \mathrm{a}$ & 1.4552 & 2.0733 & 2.3345 & 1.4535 & 2.0966 & 2.3760 \\
\hline $\mathrm{Cu}^{+}$ & methyl & $(2: 1)$ & homo, $\mathrm{C}_{2} \mathrm{~b}$ & 1.4680 & 2.0733 & 2.3344 & 1.4747 & 2.0967 & 2.3759 \\
\hline $\mathrm{Cu}^{+}$ & dimethyl & $(1: 1)$ & $\mathrm{C}_{2}$ & 1.4735 & 2.1260 & 2.4075 & 1.4753 & 2.1582 & 2.4691 \\
\hline $\mathrm{Cu}^{+}$ & dimethyl & $(2: 1)$ & het, $\mathrm{S}_{4}$ & 1.4680 & 2.0659 & 2.3897 & 1.4708 & 2.0925 & 2.4235 \\
\hline $\mathrm{Cu}^{+}$ & dimethyl & $(2: 1)$ & homo, $\mathrm{D}_{2}$ & 1.4686 & 2.0666 & 2.3892 & 1.4710 & 2.0928 & 2.4233 \\
\hline $\mathrm{Li}^{+}$ & $\mathrm{H}$ & $(1: 1)$ & $\mathrm{C}_{2}$ & 1.4603 & 2.1021 & 2.3732 & 1.4571 & 2.1273 & 2.4202 \\
\hline $\mathrm{Li}^{+}$ & $\mathrm{H}$ & $(2: 1)$ & het, $\mathrm{S}_{4}$ & 1.4591 & 2.0966 & 2.3651 & 1.4559 & 2.1179 & 2.4078 \\
\hline $\mathrm{Li}^{+}$ & $\mathrm{H}$ & $(2: 1)$ & homo, $\mathrm{D}_{2}$ & 1.4593 & 2.0964 & 2.3650 & 1.4559 & 2.1182 & 2.4083 \\
\hline $\mathrm{Li}^{+}$ & methyl & $(1: 1)$ & $\mathrm{C}_{2}$ & 1.4671 & 2.0891 & 2.3584 & 1.4678 & 2.1160 & 2.4075 \\
\hline $\mathrm{Li}^{+}$ & methyl & $(2: 1)$ & het, $\mathrm{C}_{1}$ & 1.4651 & 2.0840 & 2.3524 & 1.4645 & 2.1070 & 2.3936 \\
\hline $\mathrm{Li}^{+}$ & methyl & $(2: 1)$ & homo, $\mathrm{C}_{2} \mathrm{a}$ & 1.4649 & 2.0838 & 2.3515 & 1.4643 & 2.1068 & 2.3940 \\
\hline $\mathrm{Li}^{+}$ & methyl & $(2: 1)$ & homo, $\mathrm{C}_{2} \mathrm{~b}$ & 1.4651 & 2.0836 & 2.3531 & 1.4644 & 2.1069 & 2.3939 \\
\hline $\mathrm{Li}^{+}$ & dimethyl & $(1: 1)$ & $\mathrm{C}_{2}$ & 1.4758 & 2.0744 & 2.3418 & 1.4784 & 2.1027 & 2.3926 \\
\hline $\mathrm{Li}^{+}$ & dimethyl & $(2: 1)$ & het, $\mathrm{S}_{4}$ & 1.4720 & 2.0698 & 2.3381 & 1.4727 & 2.0940 & 2.3799 \\
\hline $\mathrm{Li}^{+}$ & dimethyl & $(2: 1)$ & homo, $\mathrm{D}_{2}$ & 1.4721 & 2.0695 & 2.3369 & 1.4724 & 2.0935 & 2.3788 \\
\hline $\mathrm{Zn}^{2+}$ & $\mathrm{H}$ & $(1: 1)$ & $\mathrm{C}_{2}$ & 1.4963 & 2.2163 & 2.4959 & 1.4896 & 2.2607 & 2.5659 \\
\hline $\mathrm{Zn}^{2+}$ & $\mathrm{H}$ & $(2: 1)$ & het, $\mathrm{S}_{4}$ & 1.4867 & 2.1688 & 2.4315 & 1.4787 & 2.1947 & 2.4777 \\
\hline $\mathrm{Zn}^{2+}$ & $\mathrm{H}$ & $(2: 1)$ & homo, $\mathrm{D}_{2}$ & 1.4866 & 2.1686 & 2.4314 & 1.4787 & 2.1946 & 2.4779 \\
\hline $\mathrm{Zn}^{2+}$ & methyl & $(1: 1)$ & $\mathrm{C}_{1}$ & 1.5196 & 2.2046 & 2.4863 & 1.5261 & 2.2532 & 2.5639 \\
\hline $\mathrm{Zn}^{2+}$ & methyl & $(2: 1)$ & het, $\mathrm{C}_{1}$ & 1.5013 & 2.1525 & 2.4181 & 1.4998 & 2.1775 & 2.4669 \\
\hline $\mathrm{Zn}^{2+}$ & methyl & $(2: 1)$ & homo, $\mathrm{C}_{2} \mathrm{a}$ & 1.5009 & 2.1513 & 2.4173 & 1.4994 & 2.1757 & 2.4657 \\
\hline $\mathrm{Zn}^{2+}$ & methyl & $(2: 1)$ & homo, $\mathrm{C}_{2} \mathrm{~b}$ & 1.5012 & 2.1522 & 2.4182 & 1.5002 & 2.1775 & 2.4670 \\
\hline $\mathrm{Zn}^{2+}$ & dimethyl & $(1: 1)$ & $\mathrm{C}_{2}$ & 1.5486 & 2.1882 & 2.4722 & 1.5631 & 2.2374 & 2.5500 \\
\hline $\mathrm{Zn}^{2+}$ & dimethyl & $(2: 1)$ & het, $\mathrm{S}_{4}$ & 1.5189 & 2.1361 & 2.4046 & 1.5178 & 2.1623 & 2.4517 \\
\hline $\mathrm{Zn}^{2+}$ & dimethyl & $(2: 1)$ & homo, $\mathrm{D}_{2}$ & 1.5186 & 2.1352 & 2.4038 & 1.5180 & 2.1603 & 2.4505 \\
\hline
\end{tabular}


Table S-IV: Metal-ligand interaction energies $\left(E_{\text {inter }}\right.$, in $\left.\mathrm{kcal} / \mathrm{mol}\right)$.

\begin{tabular}{|c|c|c|c|c|c|c|c|c|c|}
\hline \multirow[b]{2}{*}{ metal } & \multirow[b]{2}{*}{ Substitution } & \multirow[b]{2}{*}{ complexation } & \multirow[b]{2}{*}{ sym } & \multicolumn{3}{|c|}{$E_{\text {inter }}, \mathrm{B} 3 \mathrm{LYP}$} & \multicolumn{3}{|c|}{$E_{\text {inter }}, \mathrm{MP} 2$} \\
\hline & & & & $\mathrm{O}$ & S & Se & $\mathrm{O}$ & $\mathrm{S}$ & $\mathrm{Se}$ \\
\hline $\mathrm{Ca}^{2+}$ & $\mathrm{H}$ & $(1: 1)$ & $\mathrm{C}_{2}$ & 62.8 & 60.6 & 69.8 & 54.2 & 53.5 & 59.1 \\
\hline $\mathrm{Ca}^{2+}$ & $\mathrm{H}$ & $(2: 1)$ & $\mathrm{D}_{2}$ & 117.7 & 108.8 & 115.7 & 103.4 & 95.4 & 104.7 \\
\hline $\mathrm{Ca}^{2+}$ & $\mathrm{H}$ & $(2: 1)$ & $\mathrm{S}_{4}$ & 117.7 & 108.8 & 115.7 & 103.5 & 95.4 & 104.7 \\
\hline $\mathrm{Cu}^{+}$ & $\mathrm{H}$ & $(1: 1)$ & $\mathrm{C}_{2}$ & 37.3 & 43.3 & 49.8 & 35.6 & 41.9 & 49.5 \\
\hline $\mathrm{Cu}^{+}$ & $\mathrm{H}$ & $(2: 1)$ & $\mathrm{D}_{2}$ & 74.3 & 86.3 & 82.9 & 73.7 & 89.1 & 95.3 \\
\hline $\mathrm{Cu}^{+}$ & $\mathrm{H}$ & $(2: 1)$ & $\mathrm{S}_{4}$ & 74.3 & 86.4 & 82.9 & 73.7 & 89.1 & 95.3 \\
\hline $\mathrm{Li}^{+}$ & $\mathrm{H}$ & $(1: 1)$ & $\mathrm{C}_{2}$ & 35.1 & 26.4 & 27.5 & 33.3 & 24.4 & 26.8 \\
\hline $\mathrm{Li}^{+}$ & $\mathrm{H}$ & $(2: 1)$ & $\mathrm{D}_{2}$ & 63.6 & 45.5 & 46.3 & 61.3 & 44.5 & 50.3 \\
\hline $\mathrm{Li}^{+}$ & $\mathrm{H}$ & $(2: 1)$ & $\mathrm{S}_{4}$ & 63.8 & 45.5 & 46.3 & 61.5 & 44.5 & 50.3 \\
\hline $\mathrm{Zn}^{2+}$ & $\mathrm{H}$ & $(1: 1)$ & $\mathrm{C}_{2}$ & 105.7 & 140.3 & 159.0 & 100.7 & 128.6 & 145.8 \\
\hline $\mathrm{Zn}^{2+}$ & $\mathrm{H}$ & $(2: 1)$ & $\mathrm{D}_{2}$ & 187.8 & 222.2 & 241.9 & 182.5 & 214.2 & 237.1 \\
\hline $\mathrm{Zn}^{2+}$ & $\mathrm{H}$ & $(2: 1)$ & $\mathrm{S}_{4}$ & 188.0 & 222.3 & 241.9 & 182.6 & 214.3 & 237.1 \\
\hline $\mathrm{Ca}^{2+}$ & methyl & $(1: 1)$ & $\mathrm{C}_{1}$ & 77.4 & 76.5 & 80.5 & 63.3 & 64.0 & 68.2 \\
\hline $\mathrm{Ca}^{2+}$ & methyl & $(2: 1)$ & $\mathrm{C}_{1}$ & 136.3 & 127.8 & 131.0 & 119.5 & 112.8 & 119.7 \\
\hline $\mathrm{Ca}^{2+}$ & methyl & $(2: 1)$ & $\mathrm{C}_{2} \mathrm{a}$ & 136.2 & 127.7 & 131.8 & 119.4 & 112.8 & 119.6 \\
\hline $\mathrm{Ca}^{2+}$ & methyl & $(2: 1)$ & $\mathrm{C}_{2} \mathrm{~b}$ & 136.2 & 127.7 & 131.9 & 119.4 & 112.8 & 119.6 \\
\hline $\mathrm{Cu}^{+}$ & methyl & $(1: 1)$ & $\mathrm{C}_{1}$ & 41.5 & 49.9 & 55.5 & 40.5 & 48.2 & 54.9 \\
\hline $\mathrm{Cu}^{+}$ & methyl & $(2: 1)$ & $\mathrm{C}_{1}$ & 81.5 & 96.2 & 98.8 & 81.8 & 100.4 & 105.8 \\
\hline $\mathrm{Cu}^{+}$ & methyl & $(2: 1)$ & $\mathrm{C}_{2} \mathrm{a}$ & 80.7 & 96.0 & 98.8 & 82.3 & 100.6 & 106.3 \\
\hline $\mathrm{Cu}^{+}$ & methyl & $(2: 1)$ & $\mathrm{C}_{2} \mathrm{~b}$ & 82.1 & 96.3 & 98.8 & 81.3 & 100.6 & 106.3 \\
\hline $\mathrm{Li}^{+}$ & methyl & $(1: 1)$ & $\mathrm{C}_{1}$ & 39.9 & 31.8 & 32.2 & 37.6 & 29.3 & 30.9 \\
\hline $\mathrm{Li}^{+}$ & methyl & $(2: 1)$ & $\mathrm{C}_{1}$ & 70.9 & 54.1 & 53.7 & 68.4 & 52.7 & 57.3 \\
\hline $\mathrm{Li}^{+}$ & methyl & $(2: 1)$ & $\mathrm{C}_{2} \mathrm{a}$ & 70.7 & 54.0 & 53.6 & 68.3 & 52.6 & 57.3 \\
\hline $\mathrm{Li}^{+}$ & methyl & $(2: 1)$ & $\mathrm{C}_{2} \mathrm{~b}$ & 70.7 & 54.1 & 53.7 & 68.3 & 52.7 & 57.9 \\
\hline $\mathrm{Zn}^{2+}$ & methyl & $(1: 1)$ & $\mathrm{C}_{1}$ & 126.1 & 159.4 & 175.8 & 119.2 & 145.7 & 161.0 \\
\hline $\mathrm{Zn}^{2+}$ & methyl & $(2: 1)$ & $\mathrm{C}_{1}$ & 216.2 & 262.9 & 262.9 & 210.2 & 238.6 & 258.2 \\
\hline $\mathrm{Zn}^{2+}$ & methyl & $(2: 1)$ & $\mathrm{C}_{2} \mathrm{a}$ & 216.1 & 247.0 & 262.8 & 210.0 & 238.4 & 258.0 \\
\hline $\mathrm{Zn}^{2+}$ & methyl & $(2: 1)$ & $\mathrm{C}_{2} \mathrm{~b}$ & 216.1 & 247.0 & 262.9 & 210.1 & 238.5 & 258.1 \\
\hline $\mathrm{Ca}^{2+}$ & dimethyl & $(1: 1)$ & $\mathrm{C}_{2}$ & 86.7 & 87.7 & 90.7 & 70.0 & 73.6 & 76.9 \\
\hline $\mathrm{Ca}^{2+}$ & dimethyl & $(2: 1)$ & $\mathrm{D}_{2}$ & 148.8 & 144.4 & 146.9 & 130.8 & 128.1 & 133.3 \\
\hline $\mathrm{Ca}^{2+}$ & dimethyl & $(2: 1)$ & $\mathrm{S}_{4}$ & 149.0 & 144.5 & 147.0 & 130.9 & 128.2 & 133.4 \\
\hline $\mathrm{Cu}^{+}$ & dimethyl & $(1: 1)$ & $\mathrm{C}_{2}$ & 44.7 & 56.0 & 61.0 & 43.7 & 53.9 & 60.1 \\
\hline $\mathrm{Cu}^{+}$ & dimethyl & $(2: 1)$ & $\mathrm{D}_{2}$ & 85.6 & 102.3 & 99.0 & 87.9 & 106.6 & 113.0 \\
\hline $\mathrm{Cu}^{+}$ & dimethyl & $(2: 1)$ & $\mathrm{S}_{4}$ & 85.7 & 102.5 & 99.1 & 87.9 & 106.8 & 113.3 \\
\hline $\mathrm{Li}^{+}$ & dimethyl & $(1: 1)$ & $\mathrm{C}_{2}$ & 43.1 & 36.9 & 36.8 & 40.9 & 33.8 & 34.8 \\
\hline $\mathrm{Li}^{+}$ & dimethyl & $(2: 1)$ & $\mathrm{D}_{2}$ & 74.9 & 61.9 & 60.7 & 73.2 & 59.9 & 63.6 \\
\hline $\mathrm{Li}^{+}$ & dimethyl & $(2: 1)$ & $\mathrm{S}_{4}$ & 75.1 & 61.9 & 60.8 & 73.4 & 60.0 & 63.7 \\
\hline $\mathrm{Zn}^{2+}$ & dimethyl & $(1: 1)$ & $\mathrm{C}_{2}$ & 142.3 & 176.9 & 191.6 & 134.3 & 161.5 & 175.3 \\
\hline $\mathrm{Zn}^{2+}$ & dimethyl & $(2: 1)$ & $\mathrm{D}_{2}$ & 236.4 & 268.7 & 281.8 & 231.2 & 259.7 & 277.0 \\
\hline $\mathrm{Zn}^{2+}$ & dimethyl & $(2: 1)$ & $\mathrm{S}_{4}$ & 236.7 & 269.0 & 282.1 & 231.5 & 260.1 & 277.3 \\
\hline
\end{tabular}


Table S-V: CCSD $\mathbf{T}_{1}$ values for the MP2-optimized geometries of $\mathrm{M}(\mathrm{HOOH})_{1,2}$ complexes.

\begin{tabular}{lllr}
\hline Coordination & Metal & Sym & $\mathrm{T}_{1}$ value \\
\hline$(1: 1)$ & $\mathrm{Ca}^{2+}$ & - & 0 \\
$(2: 1)$ & $\mathrm{Ca}^{2+}$ & homo & 0.000 \\
$(2: 1)$ & $\mathrm{Ca}^{2+}$ & het & 0 \\
$(1: 1)$ & $\mathrm{Cu}^{+}$ & - & 0.361 \\
$(2: 1)$ & $\mathrm{Cu}^{+}$ & homo & 0.427 \\
$(2: 1)$ & $\mathrm{Cu}^{+}$ & het & 0.429 \\
$(1: 1)$ & $\mathrm{Li}^{+}$ & - & 0 \\
$(2: 1)$ & $\mathrm{Li}^{+}$ & homo & 0 \\
$(2: 1)$ & $\mathrm{Li}^{+}$ & het & 0 \\
$(1: 1)$ & $\mathrm{Zn}^{2+}$ & - & 0 \\
$(2: 1)$ & $\mathrm{Zn}^{2+}$ & homo & 0 \\
$(2: 1)$ & $\mathrm{Zn}^{2+}$ & het & 0 \\
\hline
\end{tabular}

